\title{
PAISAGENS, PESSOAS E VIDAS RURAIS: \\ IMAGENS DE UM ESPAÇO DE VIDA
}

\author{
Tatiana Engel Gerhardt ${ }^{1}$ \\ Roberto Verdum ${ }^{1}$ \\ Ana Carrion ${ }^{1}$ \\ Andreia Burille ${ }^{1}$ \\ Cristiane Tonezer ${ }^{1}$ \\ Deise Lisboa Riquinho ${ }^{1}$ \\ Eliziane Nicolodi Francescato Ruiz ${ }^{1}$ \\ Joana Cicconeto ${ }^{1}$ \\ Joannie Fachinelli Soares ${ }^{1}$ \\ Luciana Alcântara ${ }^{1}$ \\ Potiguara de Oliveira Paz ${ }^{1}$ \\ Vilma Constância Fioravante dos Santos ${ }^{1}$
}

A exposição "Abordagem interdisciplinar: paisagens, pessoas e vidas rurais região sudeste Rio-grandense" ${ }^{2}$, apresentada inicialmente no mês de outubro de 2013 no Museu da UFRGS, é constituída de fotografias de áreas rurais da região sudeste Riograndense que ilustram paisagens, patrimônio cultural, dádivas, trabalho, produção e vidas rurais. As imagens foram capturadas pelos pesquisadores do Grupo Interdisciplinar de Pesquisa em Meio Ambiente e Desenvolvimento (GRIMAD) e do Grupo de Estudos em Saúde Coletiva (GESC) durante as pesquisas realizadas no âmbito do Programa Interdisciplinar de Pesquisa (PROINTER) do Programa de Pós-Graduação

\footnotetext{
${ }^{1}$ Universidade Federal do Rio Grande do Sul, Brasil.

${ }^{2}$ Curadores: Grupo de Pesquisa Interdisciplinar em Meio Ambiente e Desenvolvimento (GRIMAD/UFRGS); Grupo de Pesquisa em Saúde Coletiva (GESC/UFRGS); Equipe Museu da UFRGS. Créditos: Coordenadores do Grupo de Estudos em Saúde Coletiva (GESC) - Profa. Dra. Tatiana Engel Gerhardt, Profa. Dra. Marta Júlia Marques Lopes; Coordenador do Grupo Interdisciplinar de Pesquisa em Meio Ambiente e Desenvolvimento (GRIMAD) - Prof. Dr. Roberto Verdum. Autores: Ms. Ana Carrion, Dda. Andreia Burille, Dda. Cristiane Tonezer, Ms. Luciana Alcântara, Profa. Dra. Deise Lisboa Riquinho, Dra. Eliziane Nicolodi Francescato Ruiz, Ms. Joana Cicconeto, Dda. Joannie Fachinelli Soares, Mdo. Potiguara de Oliveira Paz, Prof. Dr. Roberto Verdum, Ms. Vilma Constância Fioravante dos Santos.
} 
em Desenvolvimento Rural (PGDR/UFRGS) e apresentam cenários rurais para além de um espaço apenas agrário.

As fotografias selecionadas procuram dar visibilidade para o rural como um espaço de vida evocando paisagens em que natureza e pessoas se entrelaçam e que constituem esse espaço rural e são por ele constituídas. O acúmulo de trabalhos de pesquisa em uma mesma área empírica possibilitou reflexões sobre a multidimensionalidade das relações entre o rural e o desenvolvimento, onde a temporalidade dessas relações se expressa nas imagens e em seus elementos constituintes. As fotografias trazem alguns desses elementos que caracterizam a diversidade de paisagens, pessoas e vidas rurais, colocando como desafio ao campo da Saúde Coletiva (o pensar o rural) e ao campo do Desenvolvimento Rural (o pensar a saúde):

- pela necessidade de promover o reconhecimento da saúde como parte integrante do desenvolvimento rural;

- pela escassez de estudos sobre as temáticas da saúde no meio rural;

- pelo acúmulo de pesquisas multi e interdisciplinares desenvolvidas na forma de dissertações, teses e $\operatorname{artigos}^{3}$ envolvendo diferentes olhares sobre um mesmo espaço, o rural, em temporalidades diversas;

- e pelas contribuições que estes conhecimentos podem fornecer às políticas públicas direcionadas ao rural.

Assim, pensar o rural e a saúde espelha preocupação com um cenário pouco retratado no discurso da saúde pública e coletiva. Diversamente dos olhares científicos hegemônicos sobre esse cenário, propomo-nos apreendê-lo para além de um espaço apenas agrário, produtivo e do seu quadro de distribuição epidemiológica de doenças. $\mathrm{O}$ que procuramos é dar visibilidade para o rural como um espaço de vida, evocando a voz e a expressão das pessoas que convivem com o adoecer, pessoas que constituem esse espaço e são, por ele, constituídas.

As imagens apresentadas surgem de olhares sensíveis da equipe de pesquisadores que captaram a essência de espaços de vida e que contribuíram para uma escrita densa e sensível do rural, onde a abertura para a relação com o outro e para a compreensão do seu ponto de vista, imersa na alteridade, foi capaz de produzir imagens que revelam os inúmeros contornos do rural. Ora foram utilizadas para estabelecer

${ }^{3}$ Desenvolvidos nos Programas de Pós-Graduação em Desenvolvimento Rural, em Enfermagem, em Saúde Coletiva, em Geografia da UFRGS. 
relações, enquanto um instrumento de pesquisa constituindo muitas vezes o ponto de partida, ora ilustram a experiência do encontro dos pesquisadores com interlocutores de universos distintos do seu, ora ainda revelam tentativas de se aproximar de um universo familiar a partir de um olhar distanciado. Mesmo que as imagens aqui apresentadas não tenham por base a pesquisa antropológica, elas implicaram em constante reflexividade ética, pelo tipo de relação com os participantes, sendo que os dados gerados foram mediados pela subjetividade do participante em contato direto com a subjetividade do pesquisador.

Partindo então dos diferentes usos das imagens nos diferentes empíricos do Programa de Pesquisa, agrupam-se as imagens nas seguintes categorias: paisagens, vidas rurais, dádivas, patrimônio cultural e produção e trabalho, construindo-se uma nova narrativa visual, carregada de estética e realismo, apresentada a seguir.

\section{Paisagens}

\section{A co-produção sociedade e natureza, a expressão de cultivos e culturas, de criação e procriação, externalidade de eras e quimeras!}

Elemento central em diferentes pesquisas, as paisagens representam a expressão de uma globalidade ou a decomposição em unidades que são definidas por limites naturais e pelas formas de uso e apropriação humana da natureza. Neste sentido, se propõe ao visitante uma avaliação global do conjunto da paisagem (primeira impressão) e/ou de seus elementos constituintes (modulações da percepção inicial - atratividade) a partir das experiências vividas e registradas em campo.

Conhecer os elementos da paisagem, aqueles que são marcantes, referências e valorizados; determina o reconhecimento da sua estética e dos seus elementos constitutivos. Assim, registrar as paisagens pela câmera fotográfica representa reconhecer que esses elementos são o registro de um momento, ou seja, eles evoluem e se modificam com o tempo. 


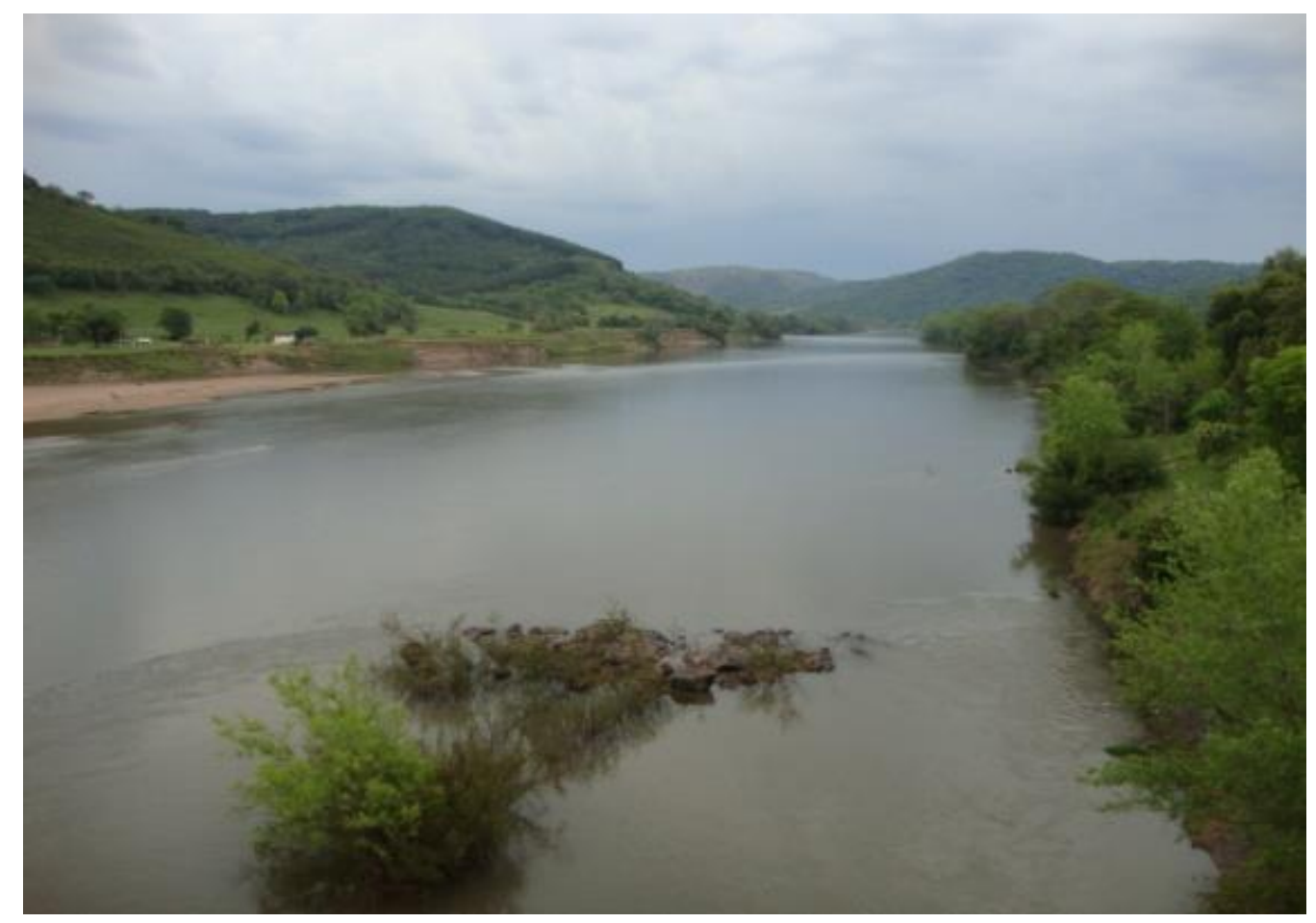

O Rio Camaquã seguindo seu curso apesar das adversidades. Canguçu/RS, 2012. Foto: Ana Carrion.

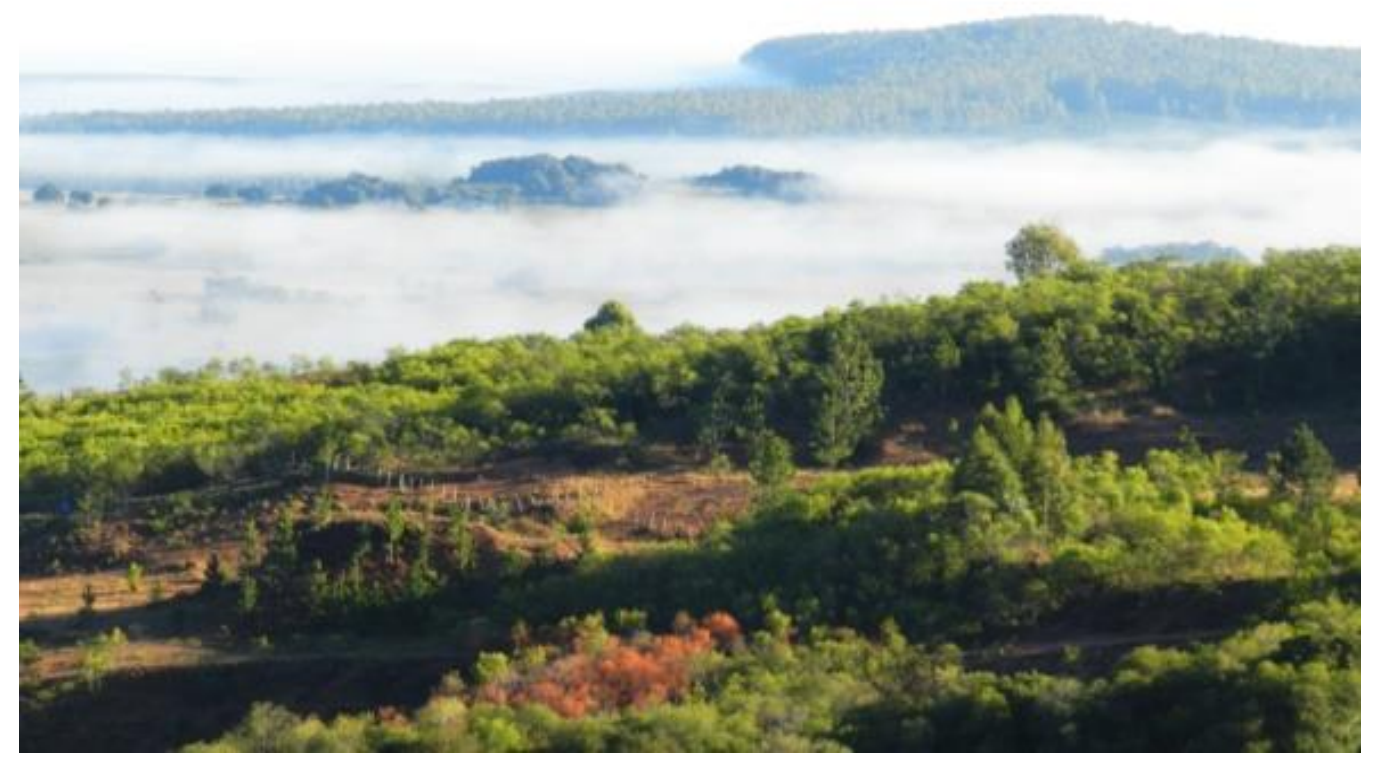

A Serra do Sudeste revela uma paisagem que vem sendo modificada pela silvicultura praticada na região. Encruzilhada do Sul/RS, 2012. Foto: Eliziane Nicolodi Francescato Ruiz. 
Tatiana Gerhardt, Roberto Verdum, Ana Carrion, Andreia Burille, Cristiane Riquinho, Eliziane Ruiz,

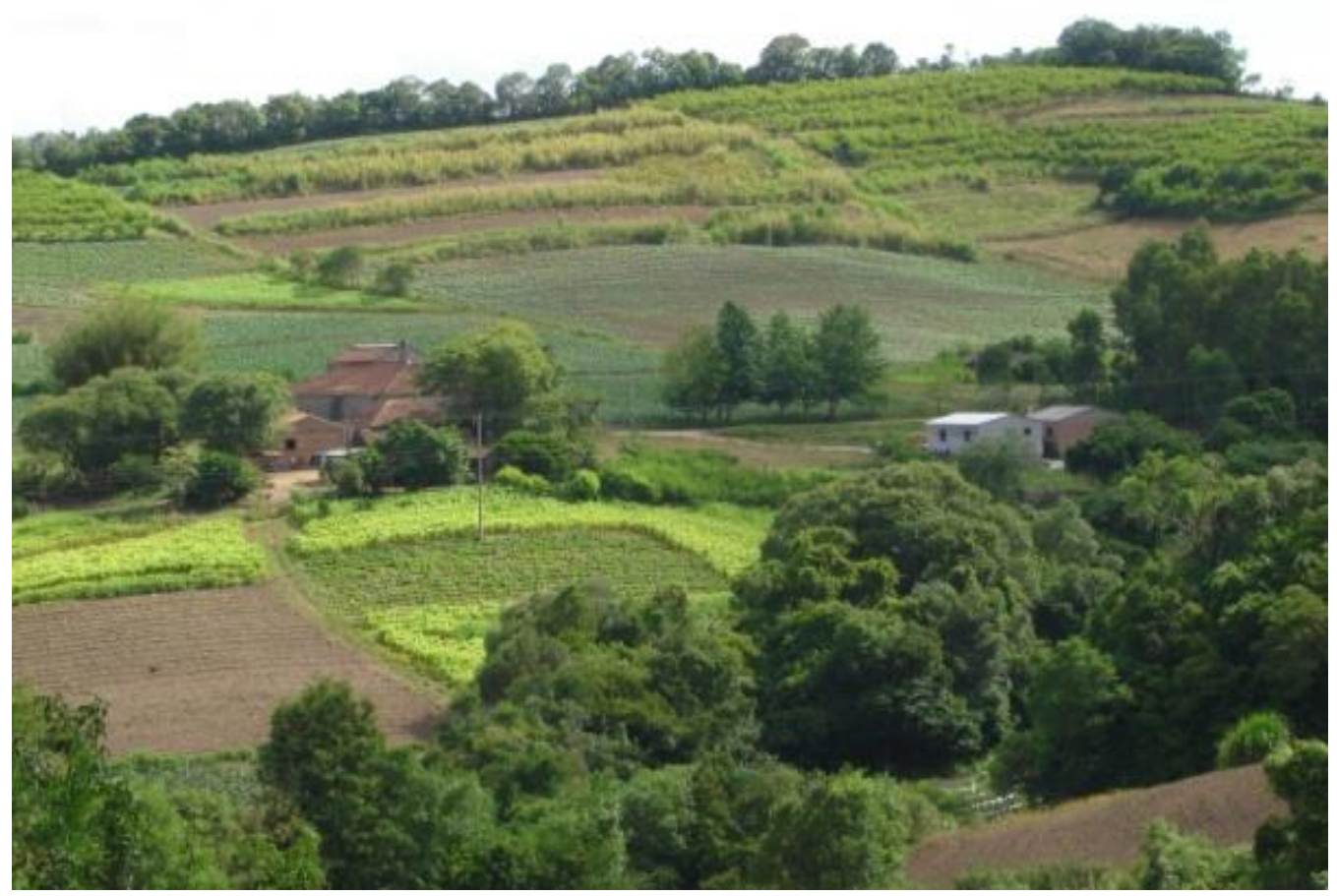

As histórias fazem famílias e paisagens que com suas cores e texturas impõem os limites do espaço rural. Localidade Rincão dos Maia, Canguçu/RS, 2011. Foto: Eliziane Nicolodi Francescato Ruiz.

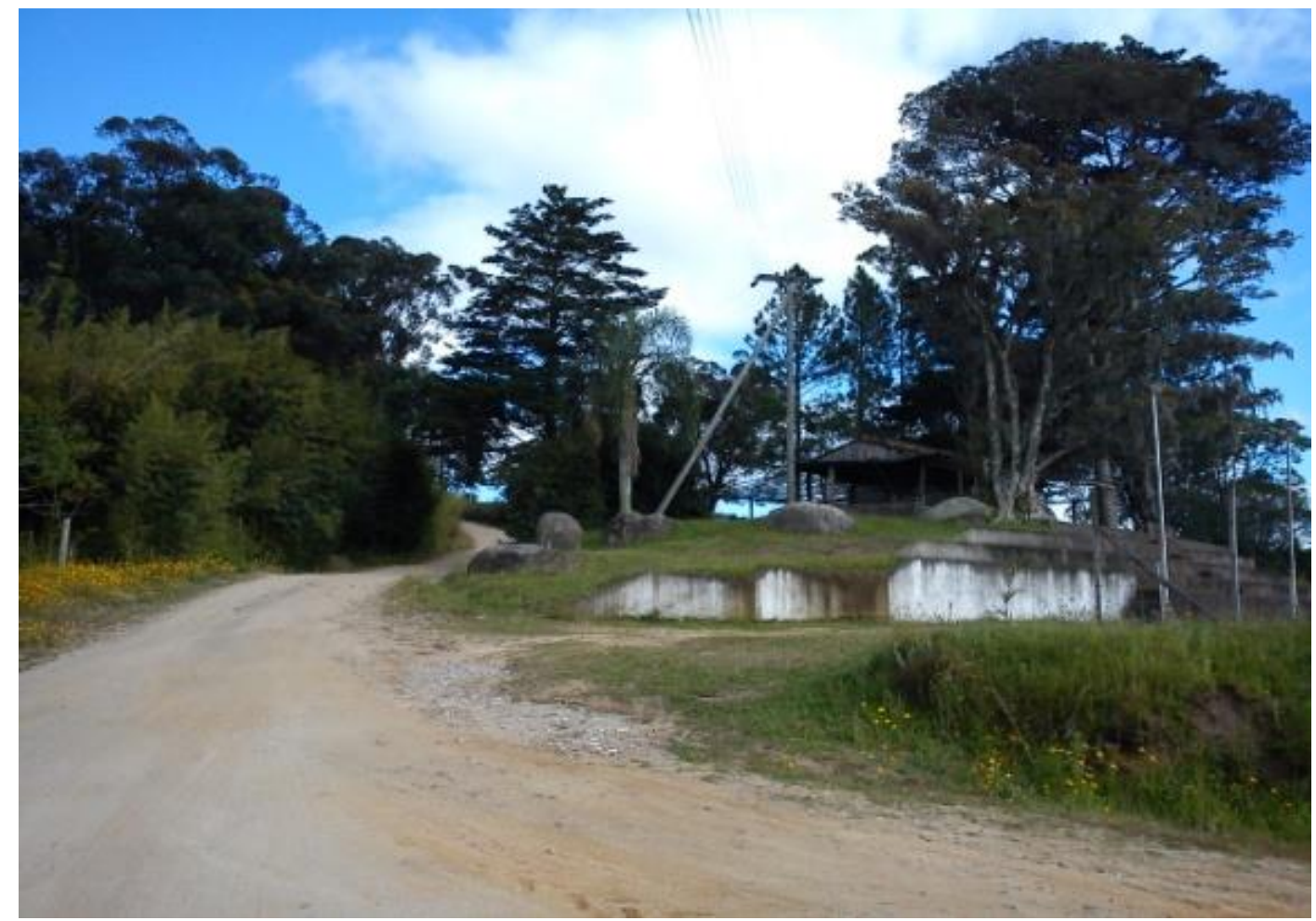

Caminhos da saúde rural: Estratégia de Saúde da Família. São Lourenço do Sul/RS, 2010. Foto: Joannie Fachinelli Soares.

Iluminuras, Porto Alegre, v. 16, n. 40, p. 345-374, ago/dez, 2015. 


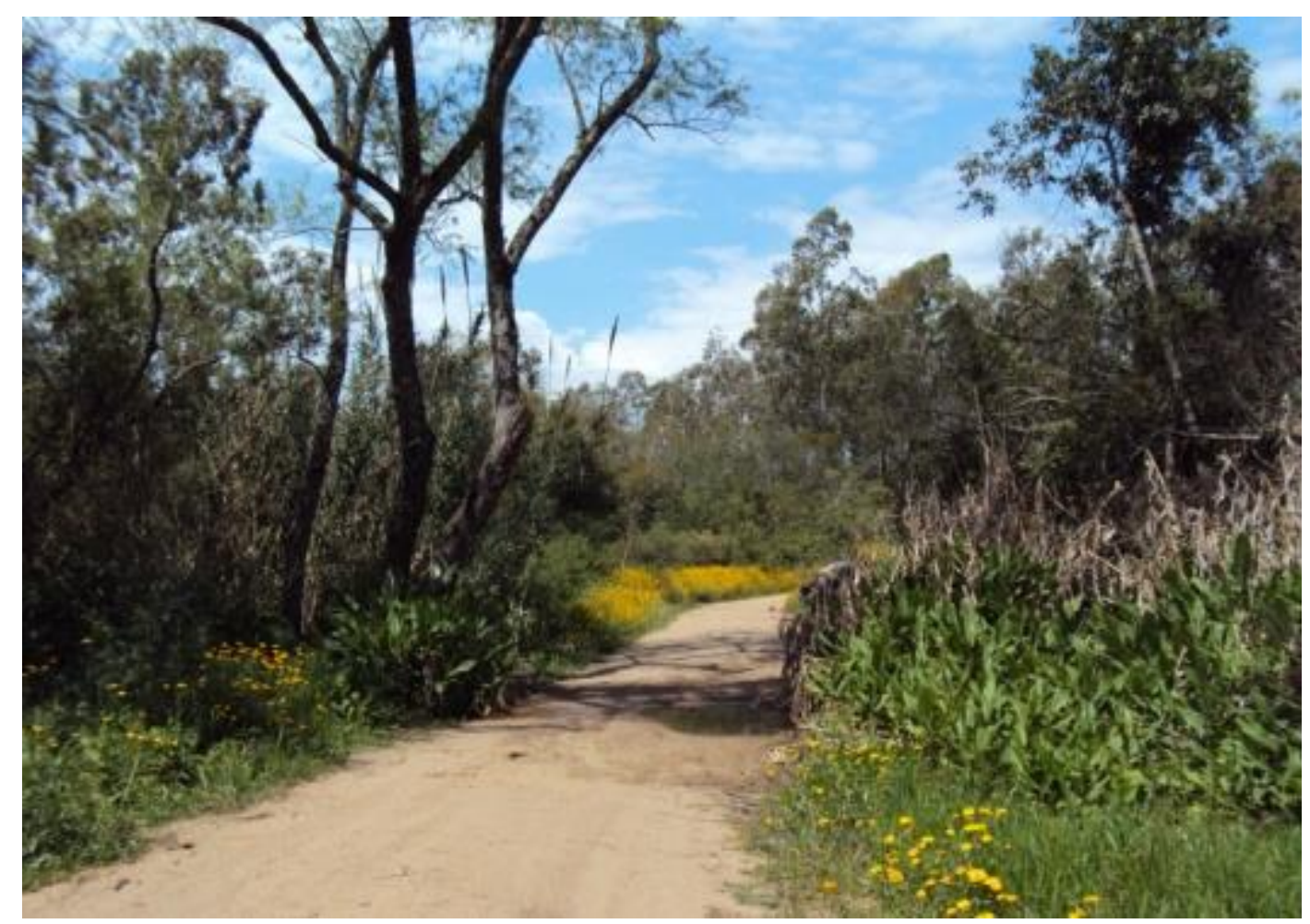

Caminhos de pesquisa: flores e cores da primavera.

Localidade Rincão dos Maia, Canguçu/RS, 2011. Foto: Vilma Contância Fioravante dos Santos.

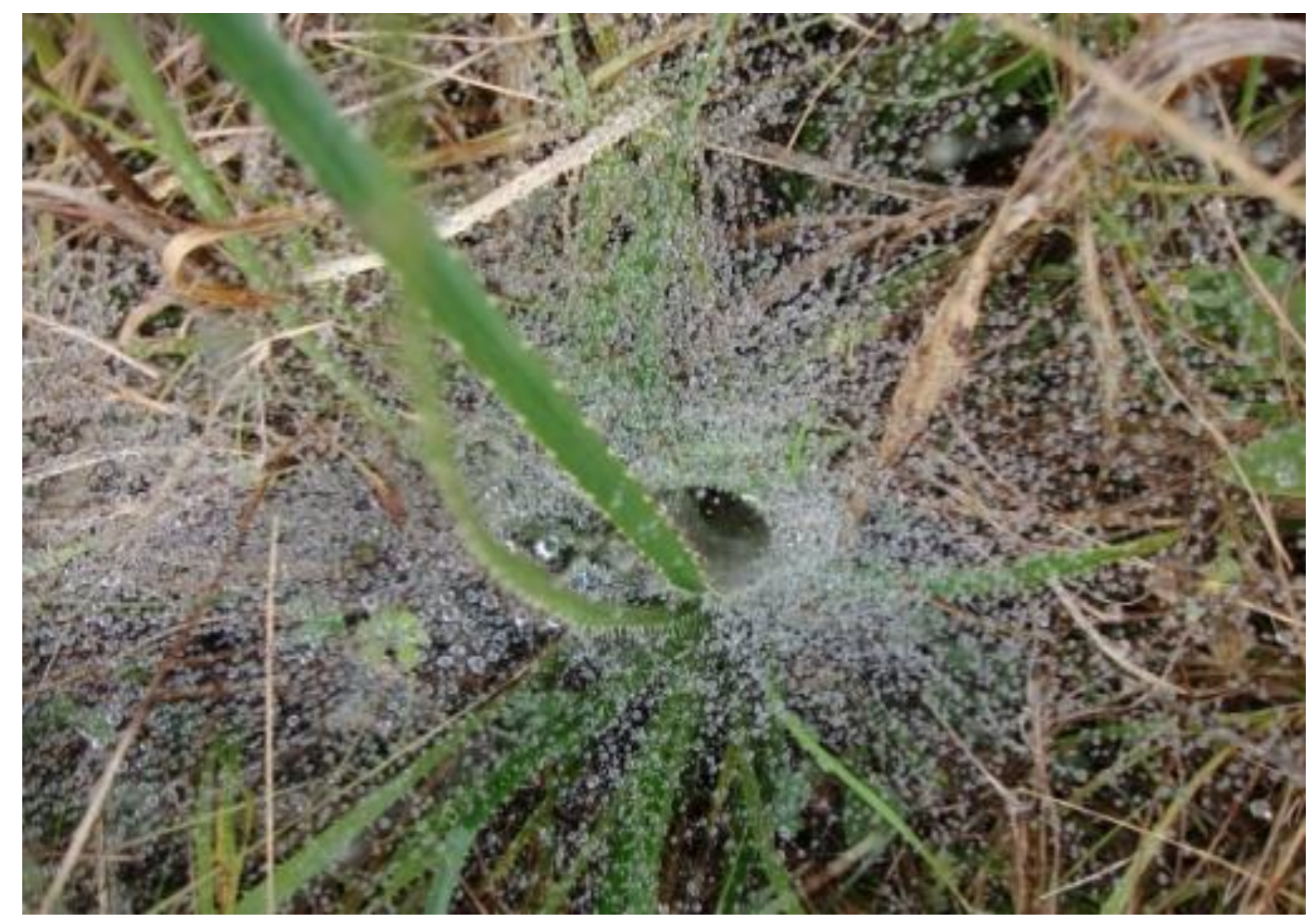

Orvalho revelando uma teia em "túnel".

Assentamento Palmeira, Canguçu/RS, 2010. Foto: Joana Cicconeto. 
Tatiana Gerhardt, Roberto Verdum, Ana Carrion, Andreia Burille, Cristiane Riquinho, Eliziane Ruiz,

Joana Cicconeto, Joannie Soares, Luciana Alcântara, Potiguara Paz e Vilma dos Santos

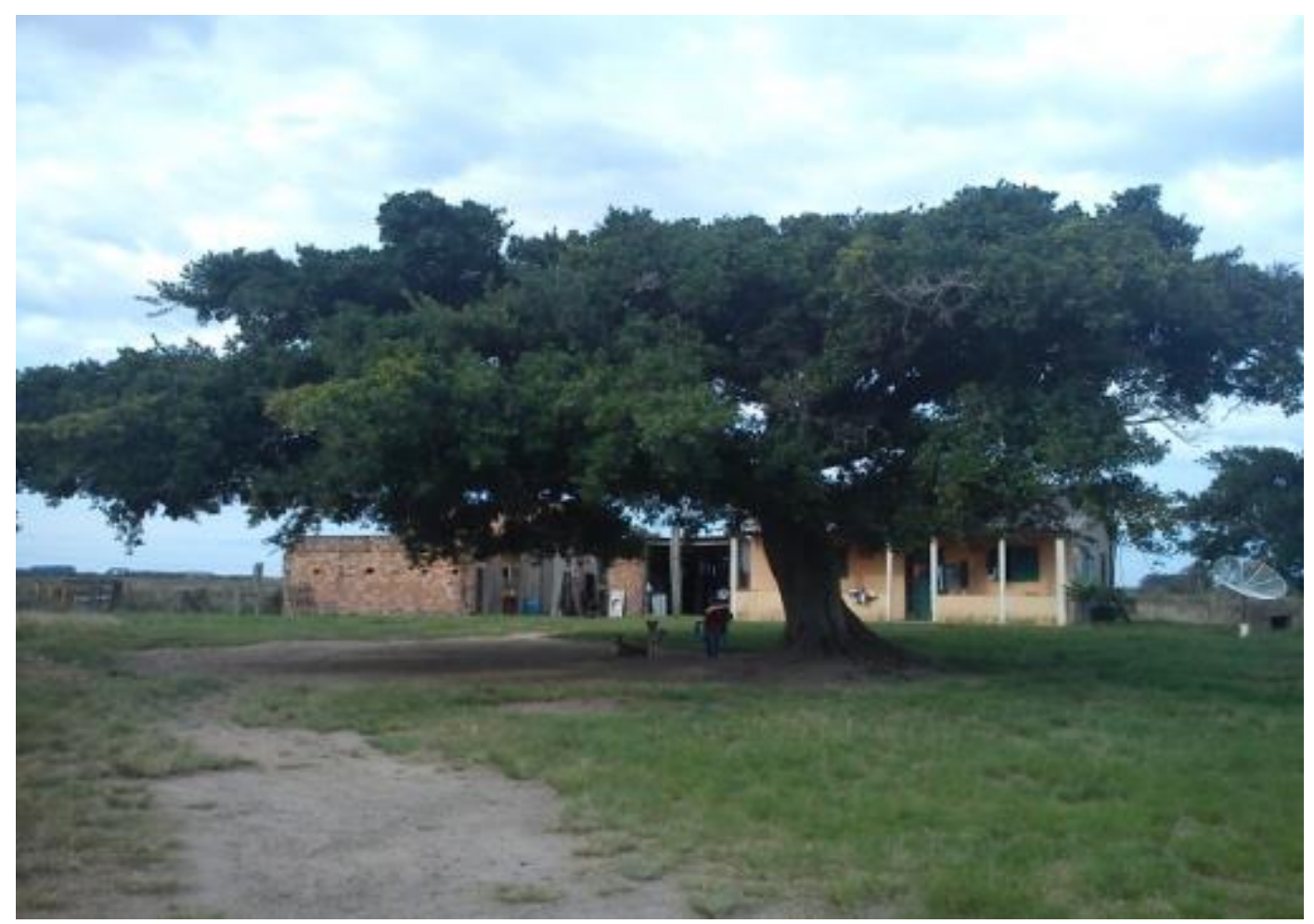

A natureza agindo: a figueira como referência e ponto de localização da comunidade rural. Assentamento Capão do Leão, Camaquã/RS, 2012. Foto: Potiguara de Oliveira Paz.

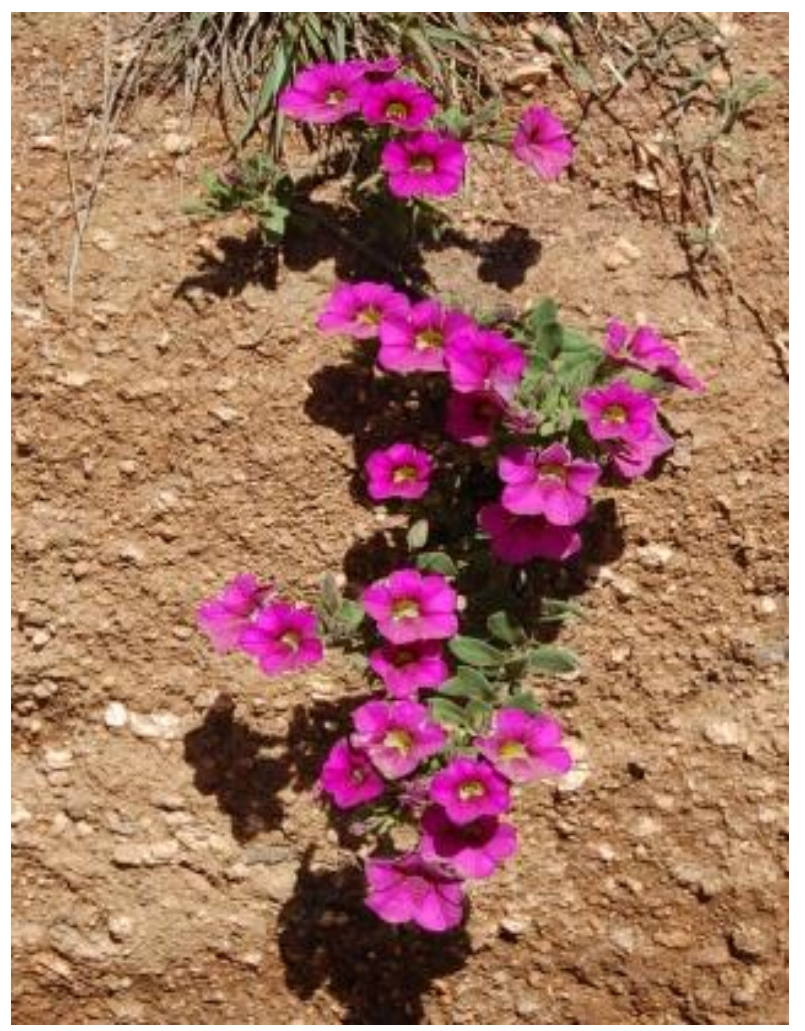

Calibrachoa excellens como espécie ornamental que potencializa a valoração das espécies locais: preservação e renda.Canguçu/RS, 2012. Foto: Roberto Verdum.

Iluminuras, Porto Alegre, v. 16, n. 40, p. 345-374, ago/dez, 2015. 


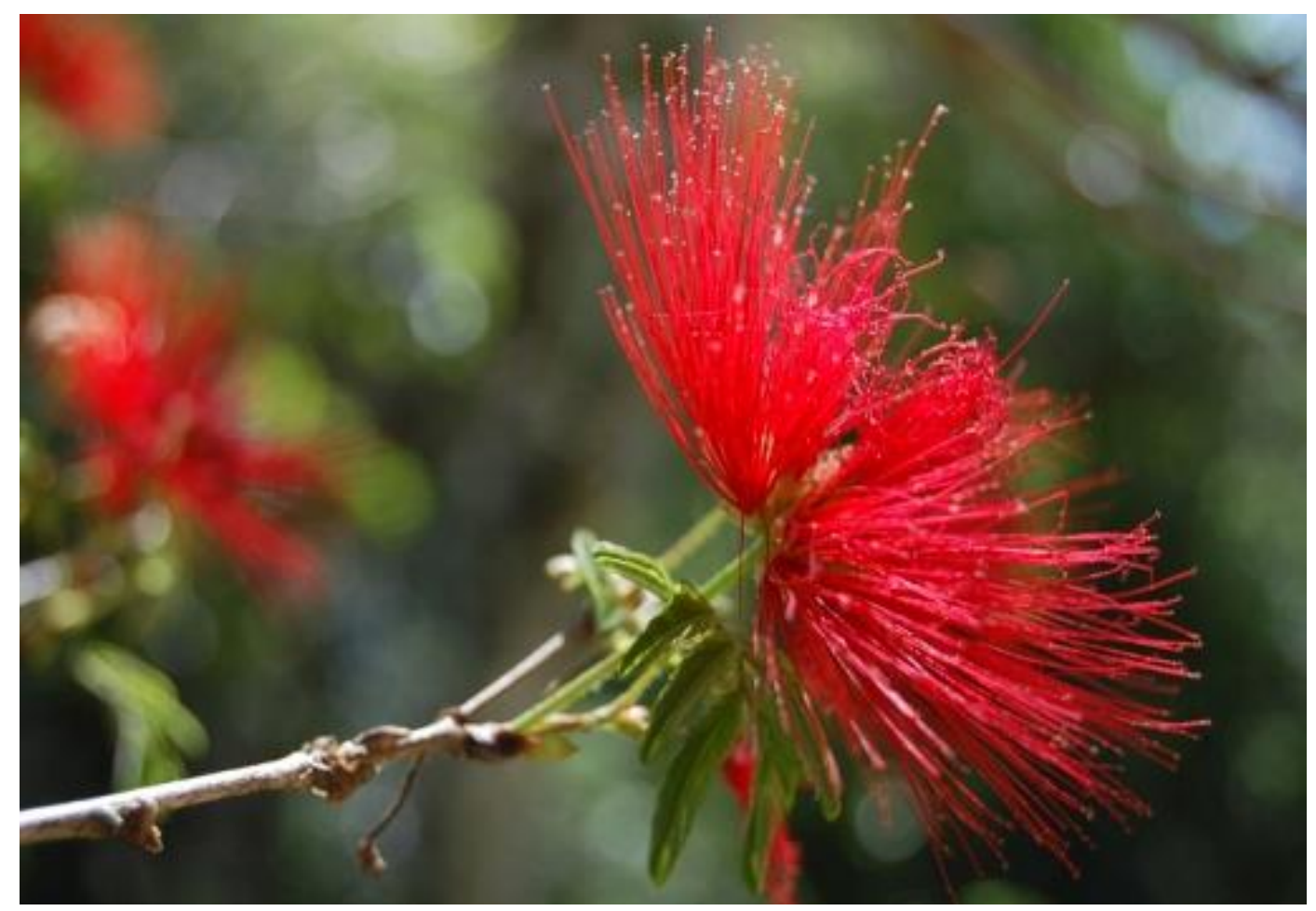

Calliandra Tweediei como espécie ornamental que potencializa a valoração das espécies locais: preservação e renda. Canguçu/RS, 2012. Foto: Roberto Verdum.

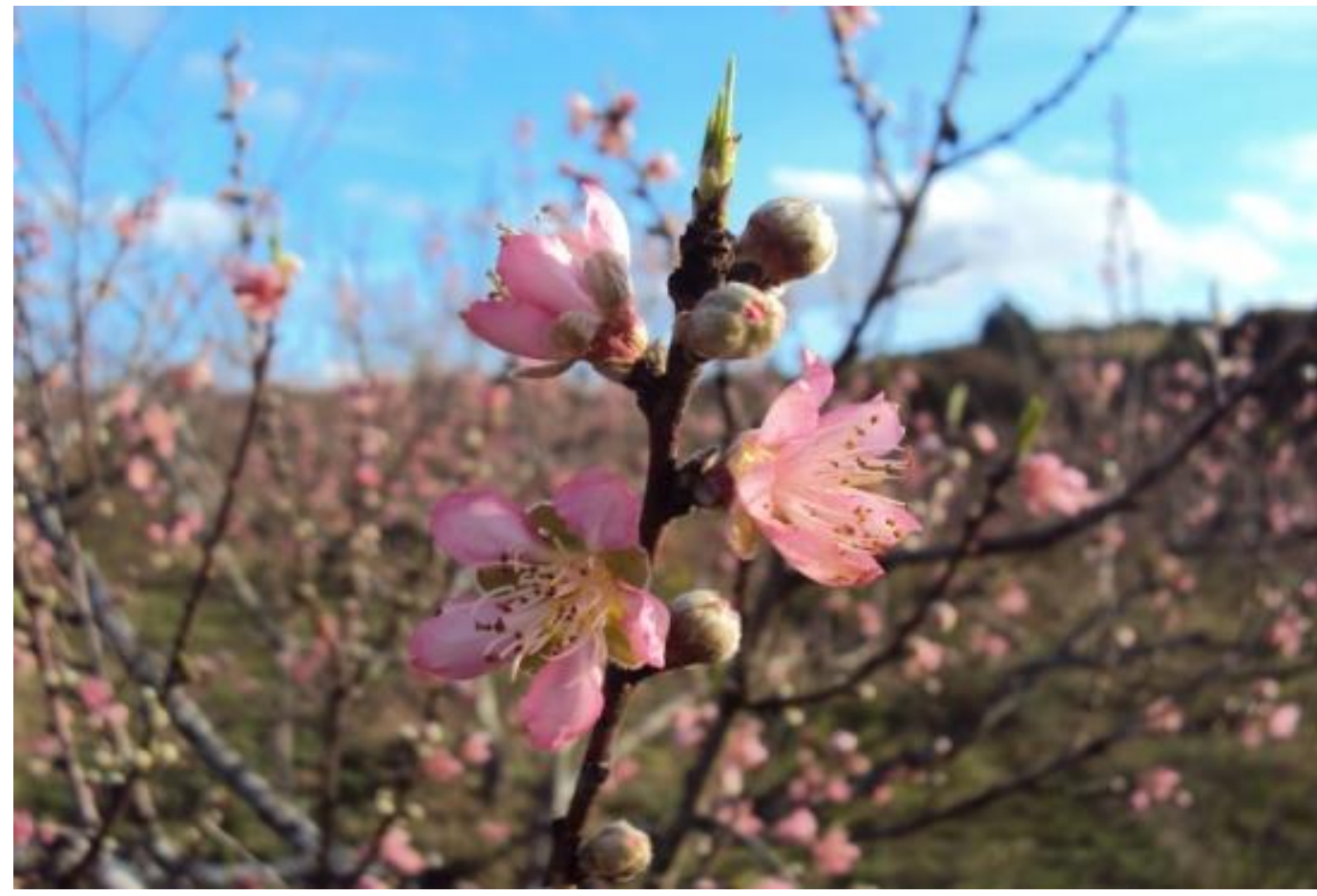

Flores de pessegueiros, cada vez mais raras. O pêssego cede lugar ao cultivo do fumo. Localidade Rincão dos Maia, Canguçu/RS, 2011. Foto: Vilma Constancia Fioravante dos Santos. 


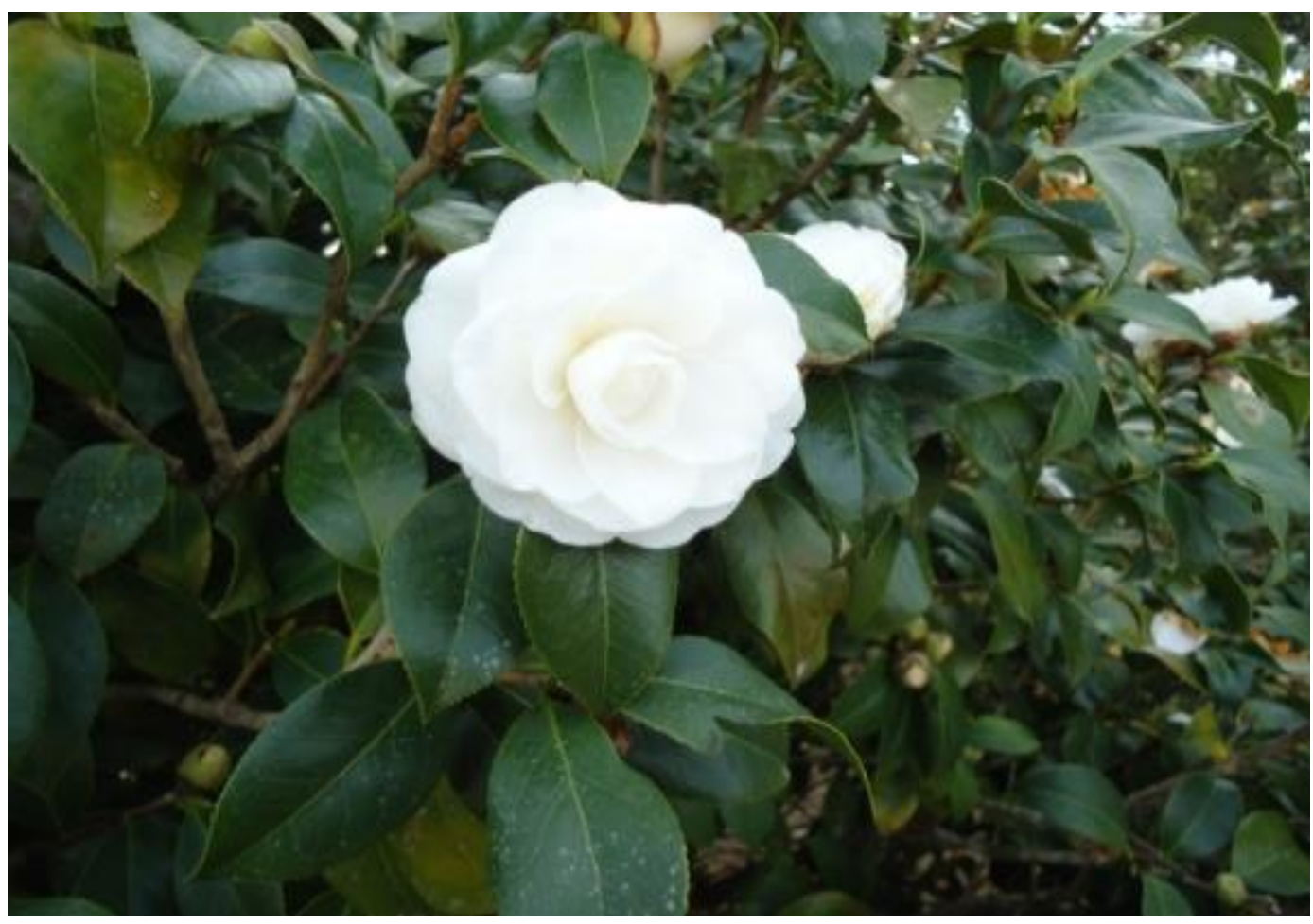

Camélias nos caminhos de pesquisa: flores e cores da primavera. Localidade Rincão dos Maia, Canguçu/RS, 2011. Foto: Andréia Burille.

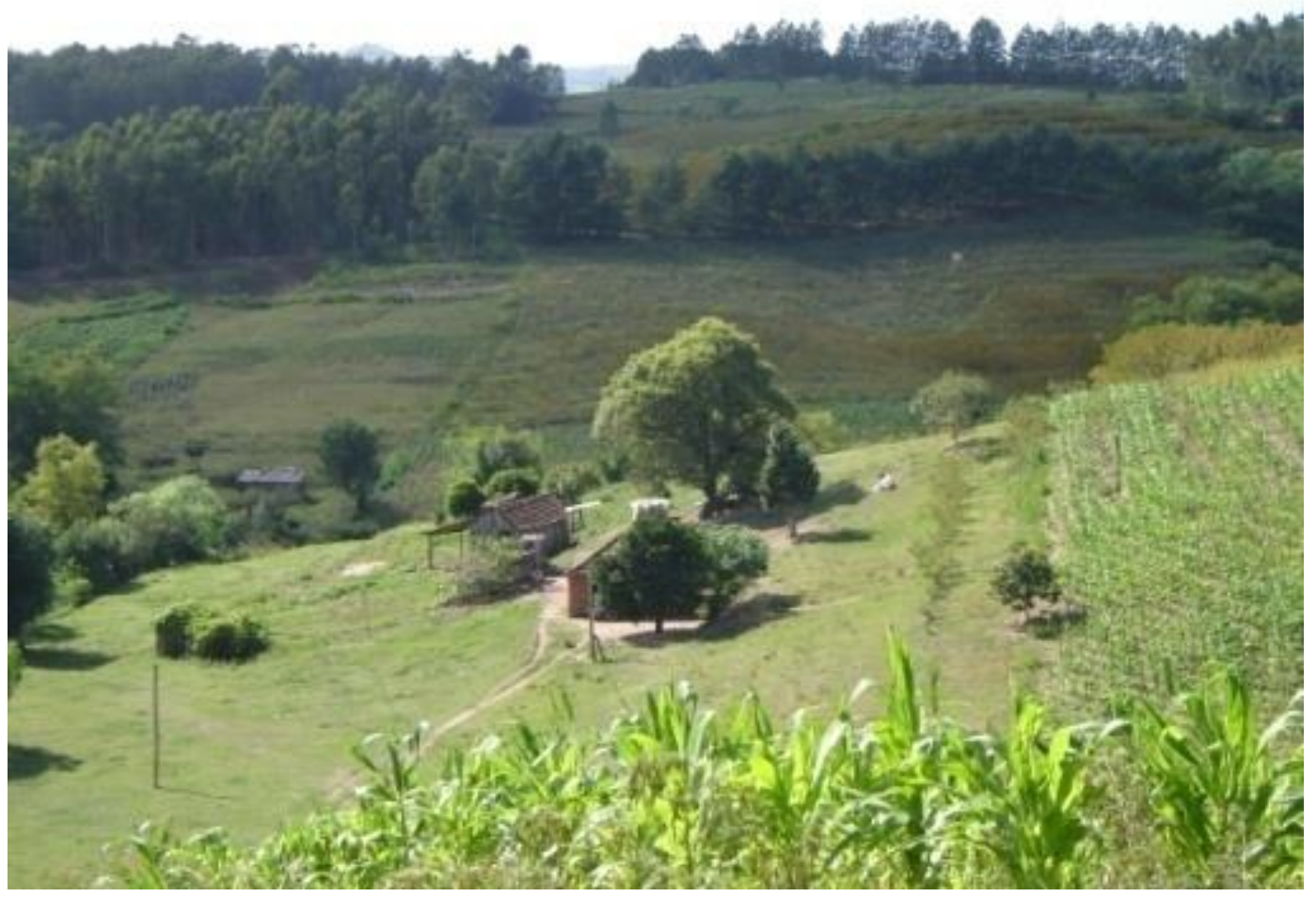

Habitando aclives e declives: casa e cultivos.

Localidade Rincão dos Maia, Canguçu/RS, 2008. Foto: Deise Lisboa Riquinho.

Iluminuras, Porto Alegre, v. 16, n. 40, p. 345-374, ago/dez, 2015. 


\section{Vidas rurais}

Espaço de nascer, crescer, envelhecer e morrer... de criação, de sofrimento, de risos e de amar - as gentes, a terra, a vida plena de sementes e frutos!

Invisibilidade de um mundo de vidas, este tema procura (re)colocar o rural enquanto espaço privilegiado de vida, para além da sua capacidade produtiva.

Abertura para a compreensão das pessoas em seu cotidiano chama a atenção para um vivido que é viabilizado pelo senso comum. Olhar para o cotidiano nesta perspectiva é colocar em relevo o mundo do homem simples e, com ele, o senso comum que "é comum não porque seja banal ou mero exterior conhecimento." Mas, "porque é conhecimento compartilhado, e assim um vivido compartilhado entre os sujeitos das relações sociais" (Martins, 2011: 54).

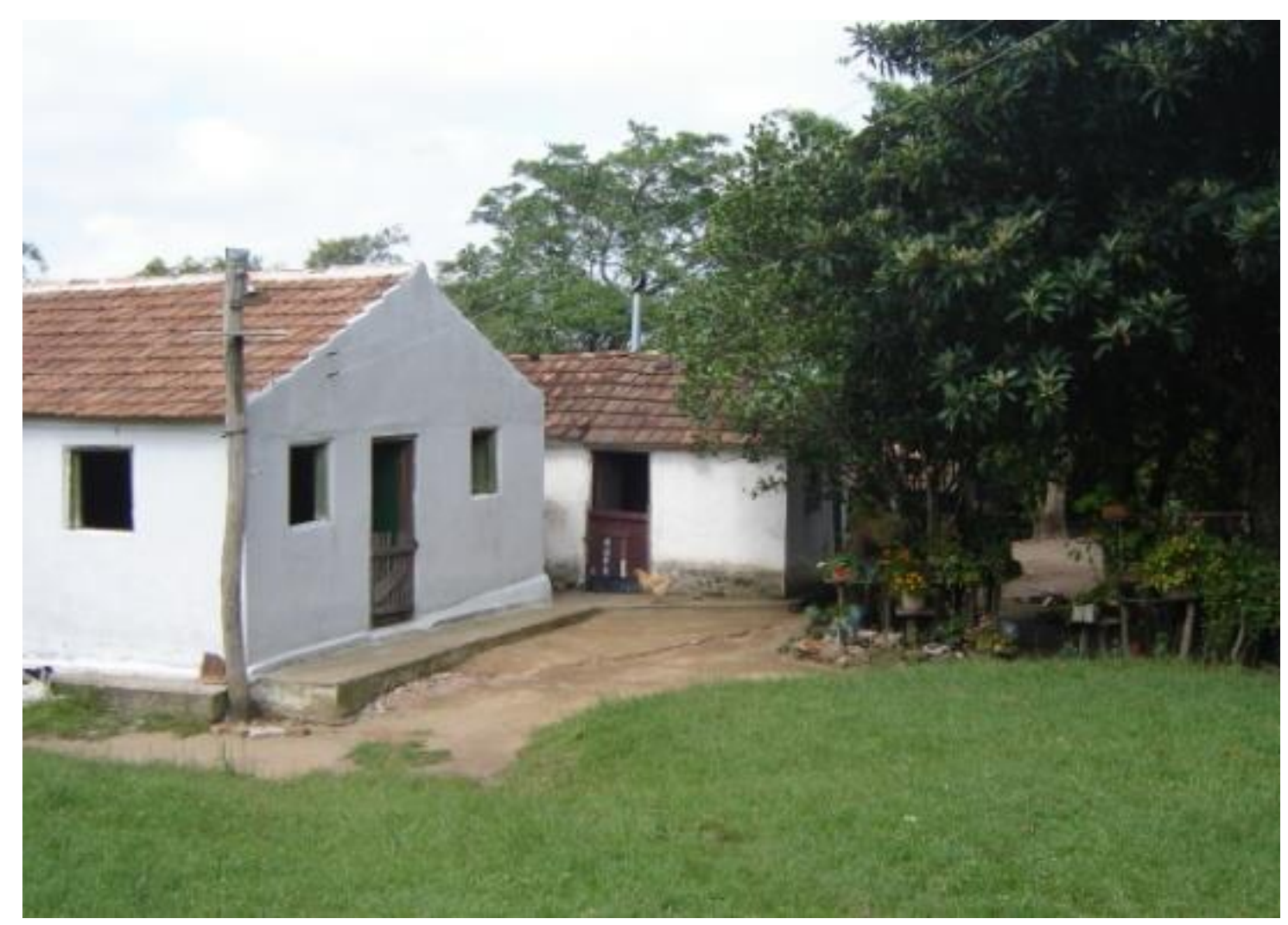

Elementos da vida rural: velhas construções, jardins e animais. Localidade Rincão dos Maia, Canguçu/RS, 2008. Foto: Deise Lisboa Riquinho. 
Tatiana Gerhardt, Roberto Verdum, Ana Carrion, Andreia Burille, Cristiane Riquinho, Eliziane Ruiz, Joana Cicconeto, Joannie Soares, Luciana Alcântara, Potiguara Paz e Vilma dos Santos

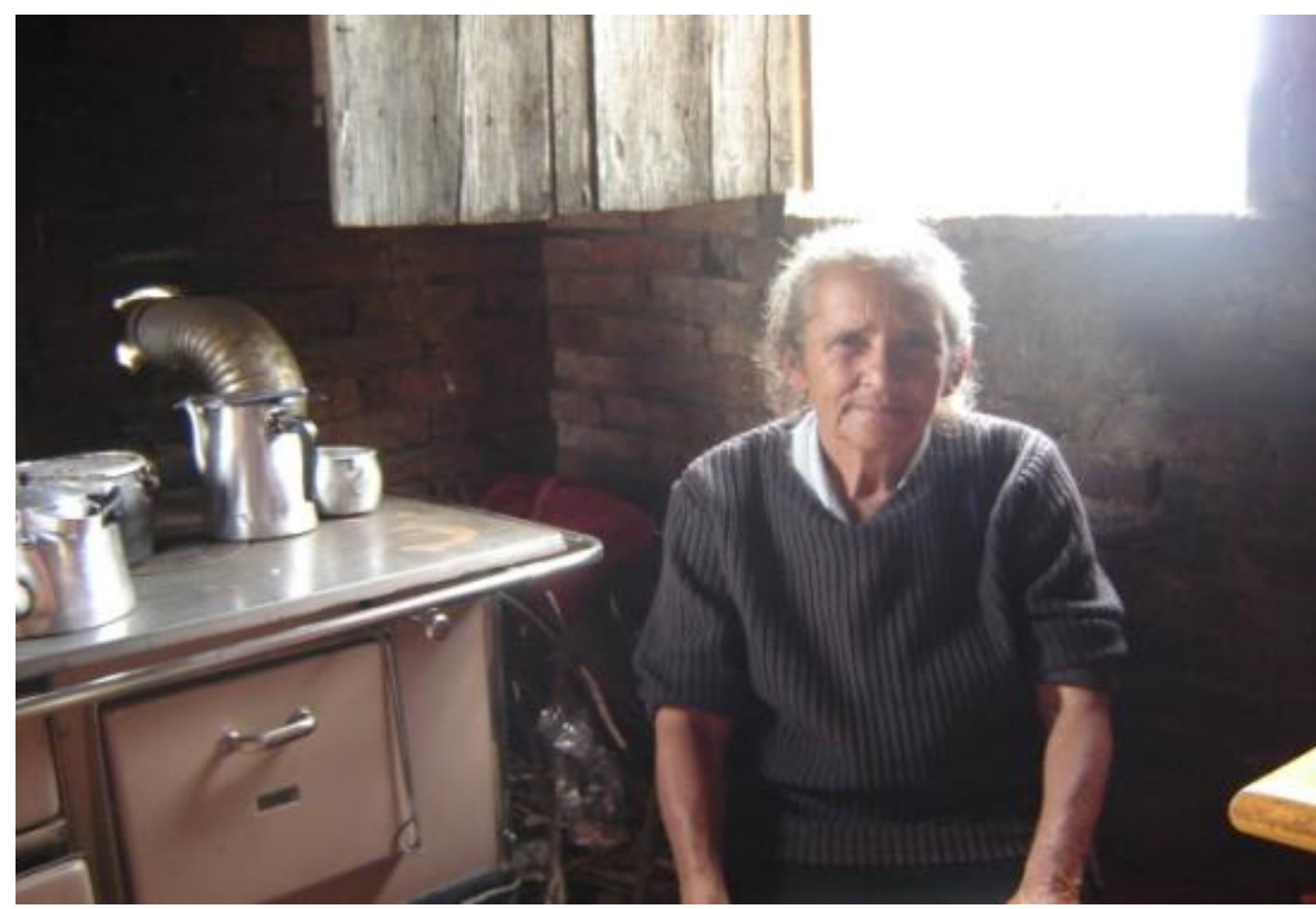

Resistir no cotidiano é preciso. Espaços de vida saudável no adoecimento crônico. Localidade Rincão dos Maia, Canguçu/RS, 2008. Foto: Deise Lisboa Riquinho.

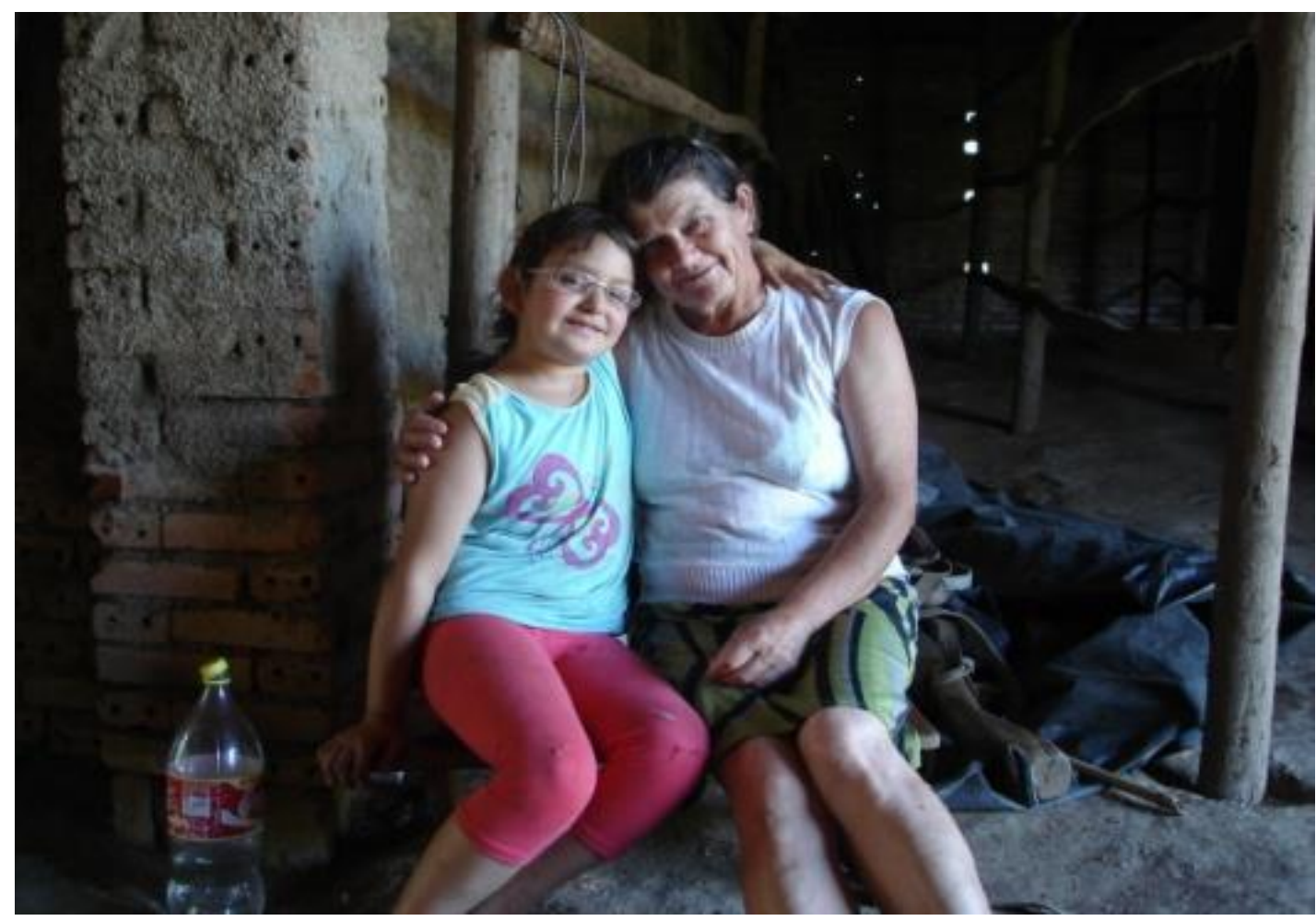

Cuidar dos netos e o respeito aos mais velhos são expressões de um modo de viver. Localidade Rincão dos Maia, Canguçu/RS, 2011. Foto: Eliziane Nicolodi Francescato Ruiz.

Iluminuras, Porto Alegre, v. 16, n. 40, p. 345-374, ago/dez, 2015. 


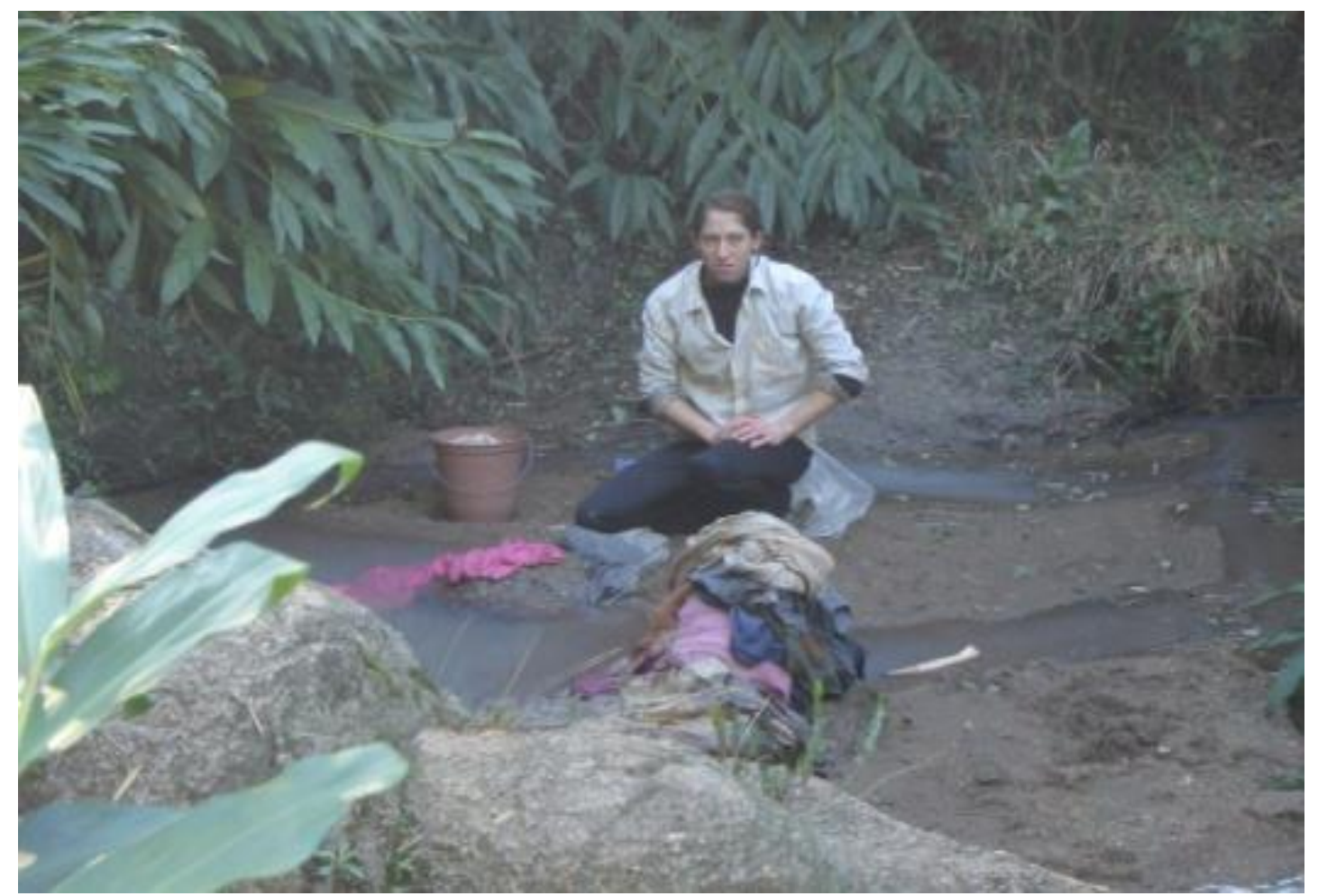

Maria, Maria, uma mulher que merece viver e amar como outra qualquer... Localidade Rincão dos Maia, Canguçu/RS, 2008. Foto: Deise Lisboa Riquinho.

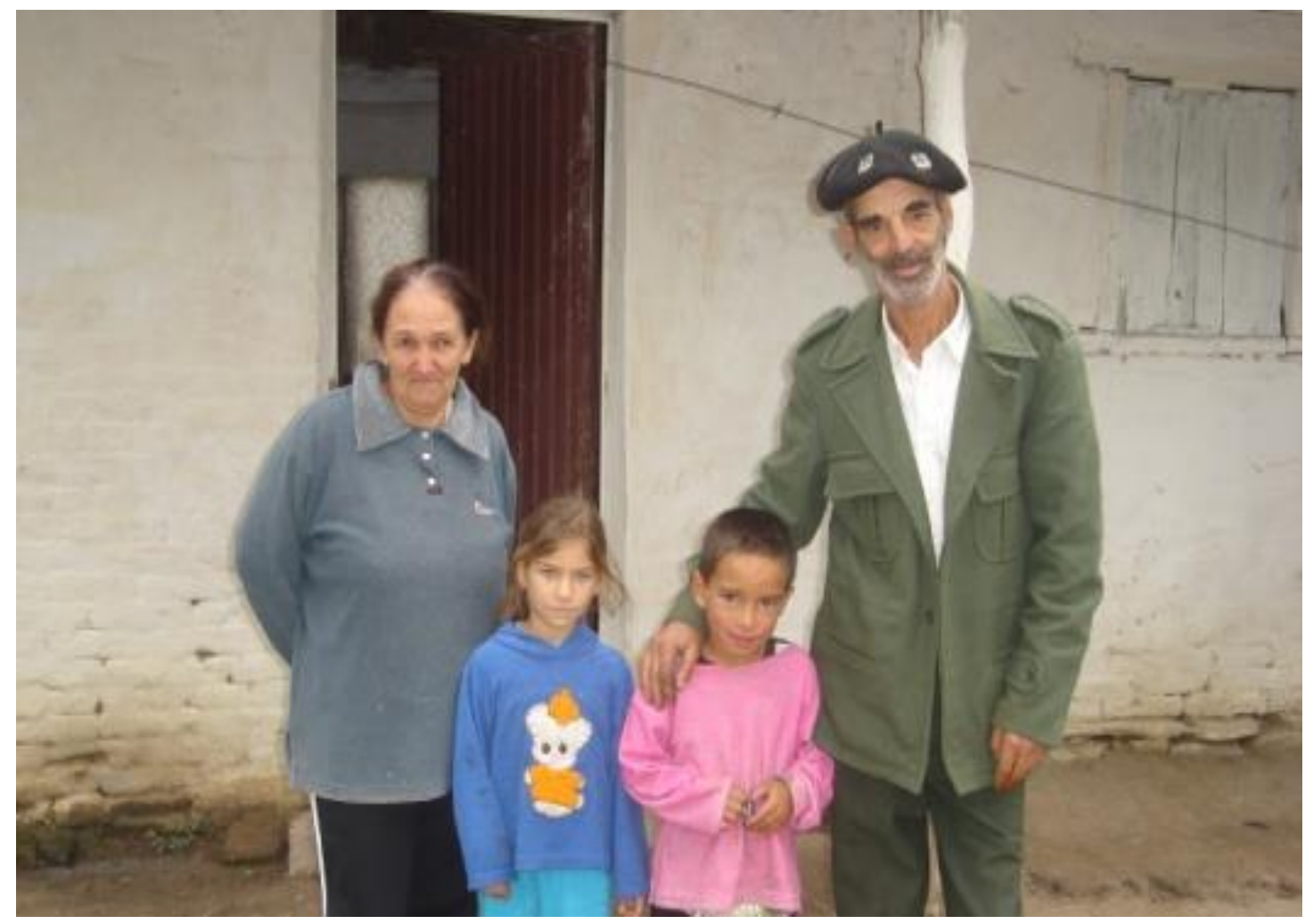

Diferentes gerações construindo redes familiares.

Santana da Boa Vista/RS, 2008. Foto: Cristiane Tonezer e Luciana Alcântara. 
Tatiana Gerhardt, Roberto Verdum, Ana Carrion, Andreia Burille, Cristiane Riquinho, Eliziane Ruiz, Joana Cicconeto, Joannie Soares, Luciana Alcântara, Potiguara Paz e Vilma dos Santos

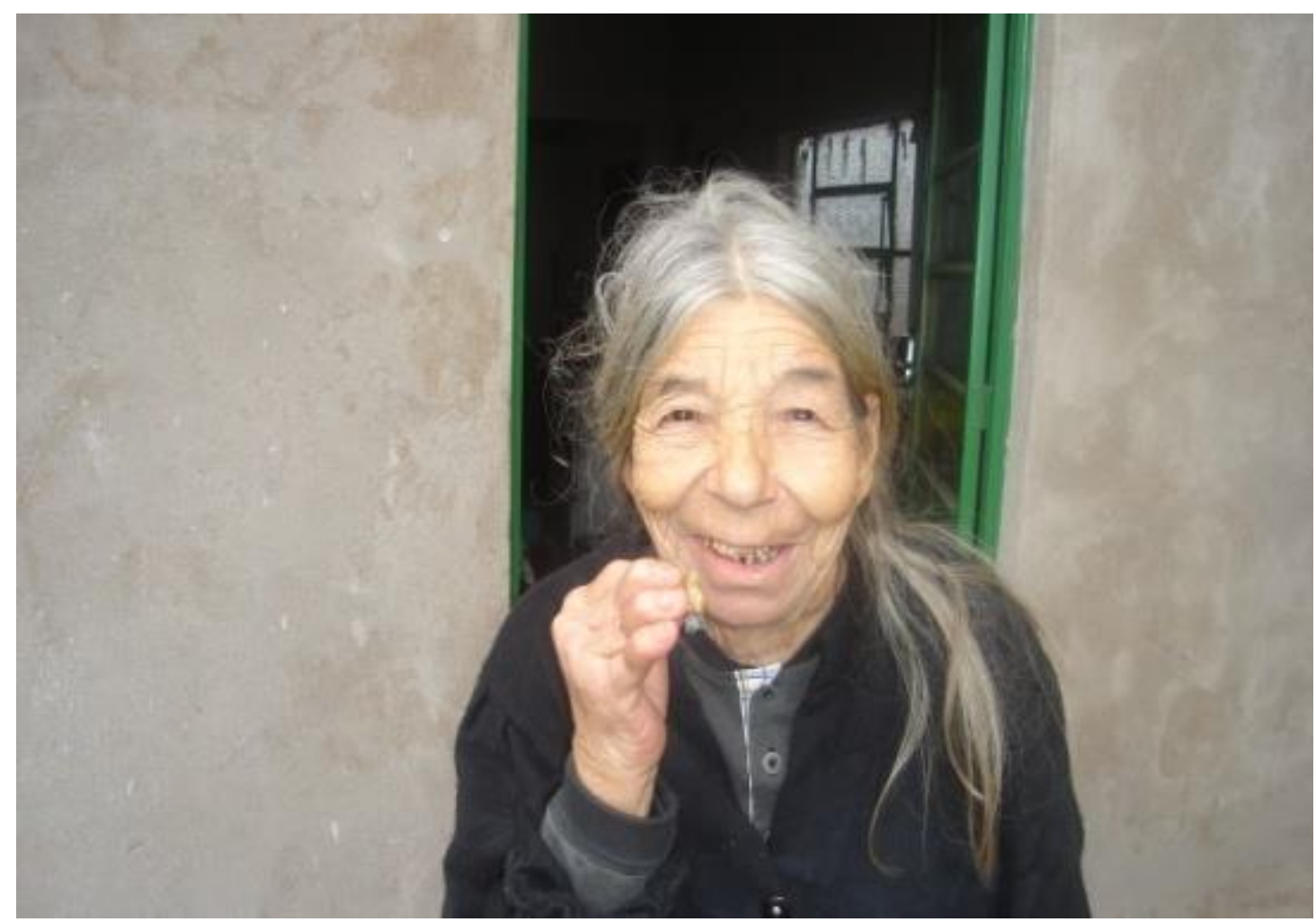

Ser feliz na velhice é...

Santana da Boa Vista/RS, 2008. Foto: Cristiane Tonezer e Luciana Alcântara.

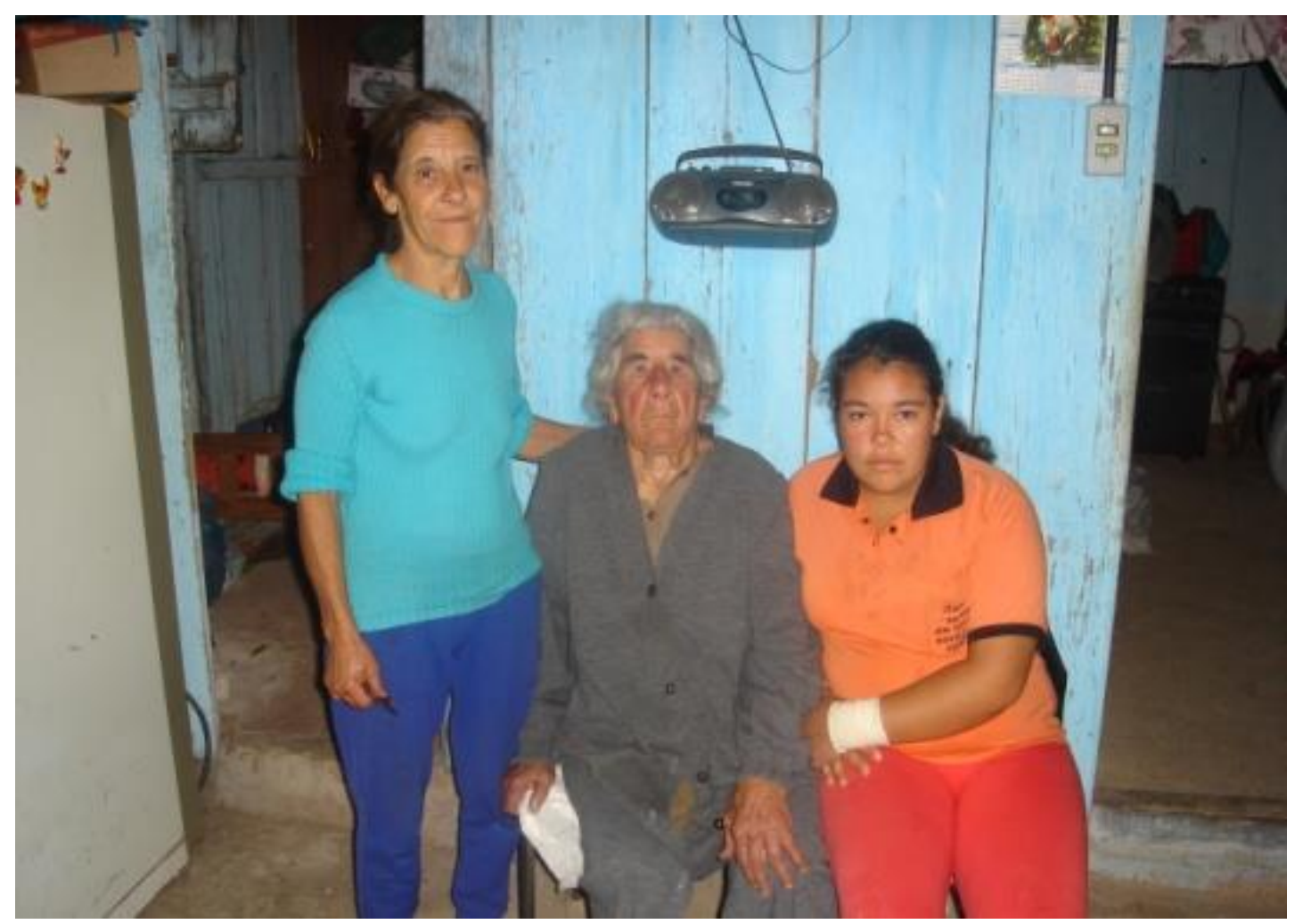

Diferentes gerações de mulheres construindo redes familiares. Santana da Boa Vista/RS, 2008. Foto: Cristiane Tonezer e Luciana Alcântara.

Iluminuras, Porto Alegre, v. 16, n. 40, p. 345-374, ago/dez, 2015. 


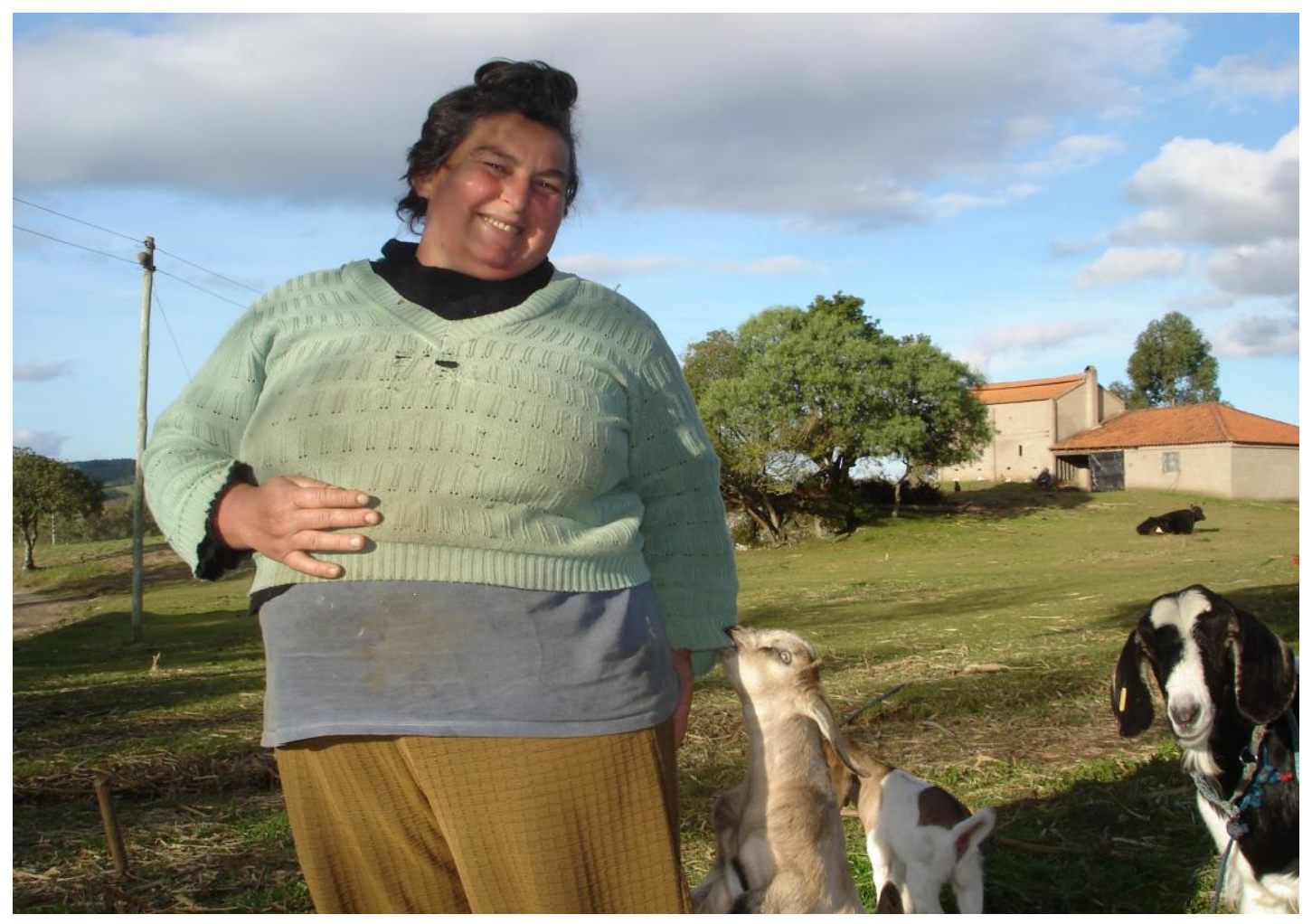

Interações com a natureza: sustento, respeito e valorização.

Localidade Rincão dos Maia, Canguçu/RS, 2011. Foto: Vilma Constância Fioravante dos Santos.

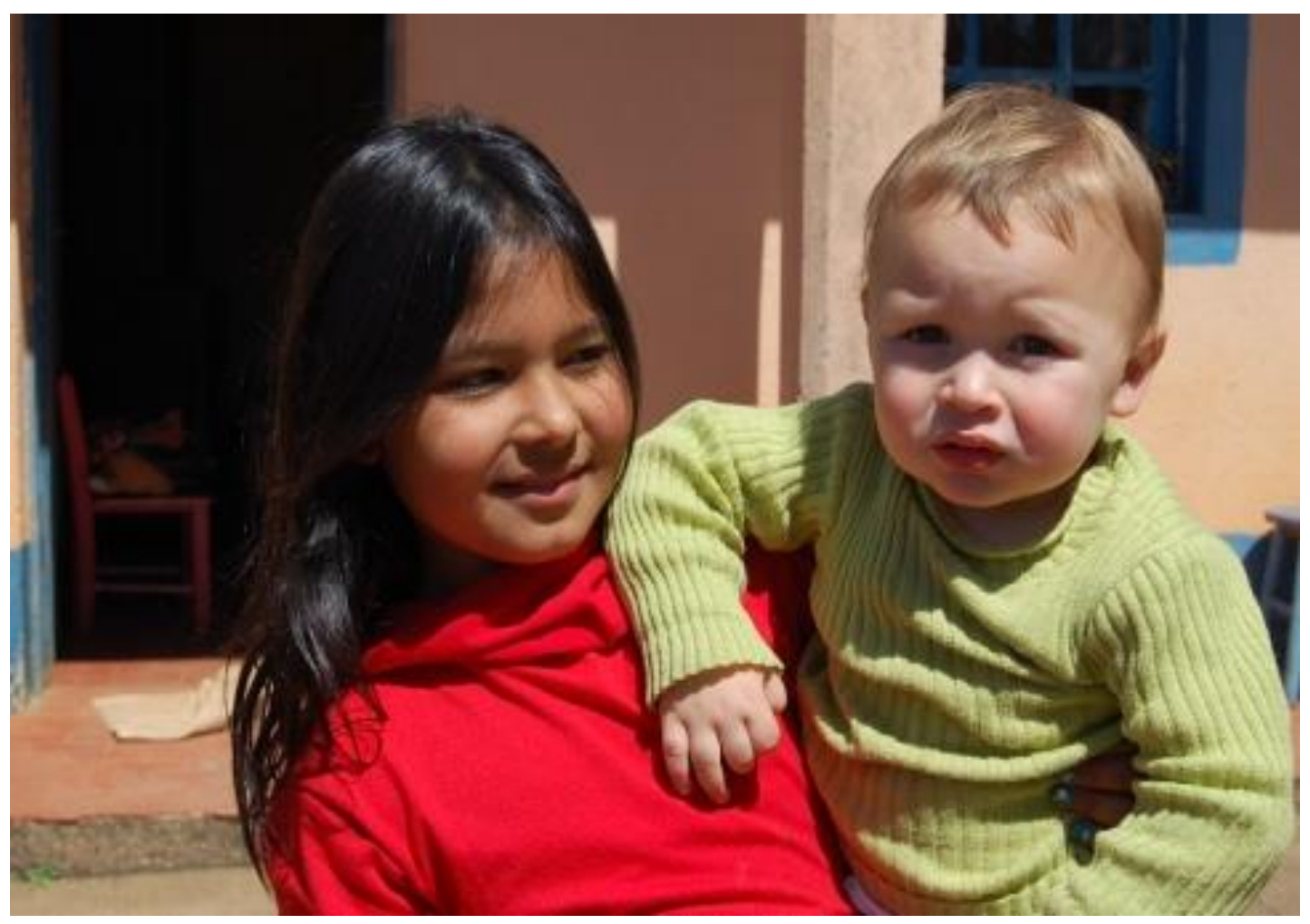

Diversidades humanas: comunidades tradicionais e migrações européias. Canguçu/RS, 2012. Foto: Roberto Verdum.

Iluminuras, Porto Alegre, v. 16, n. 40, p. 345-374, ago/dez, 2015. 


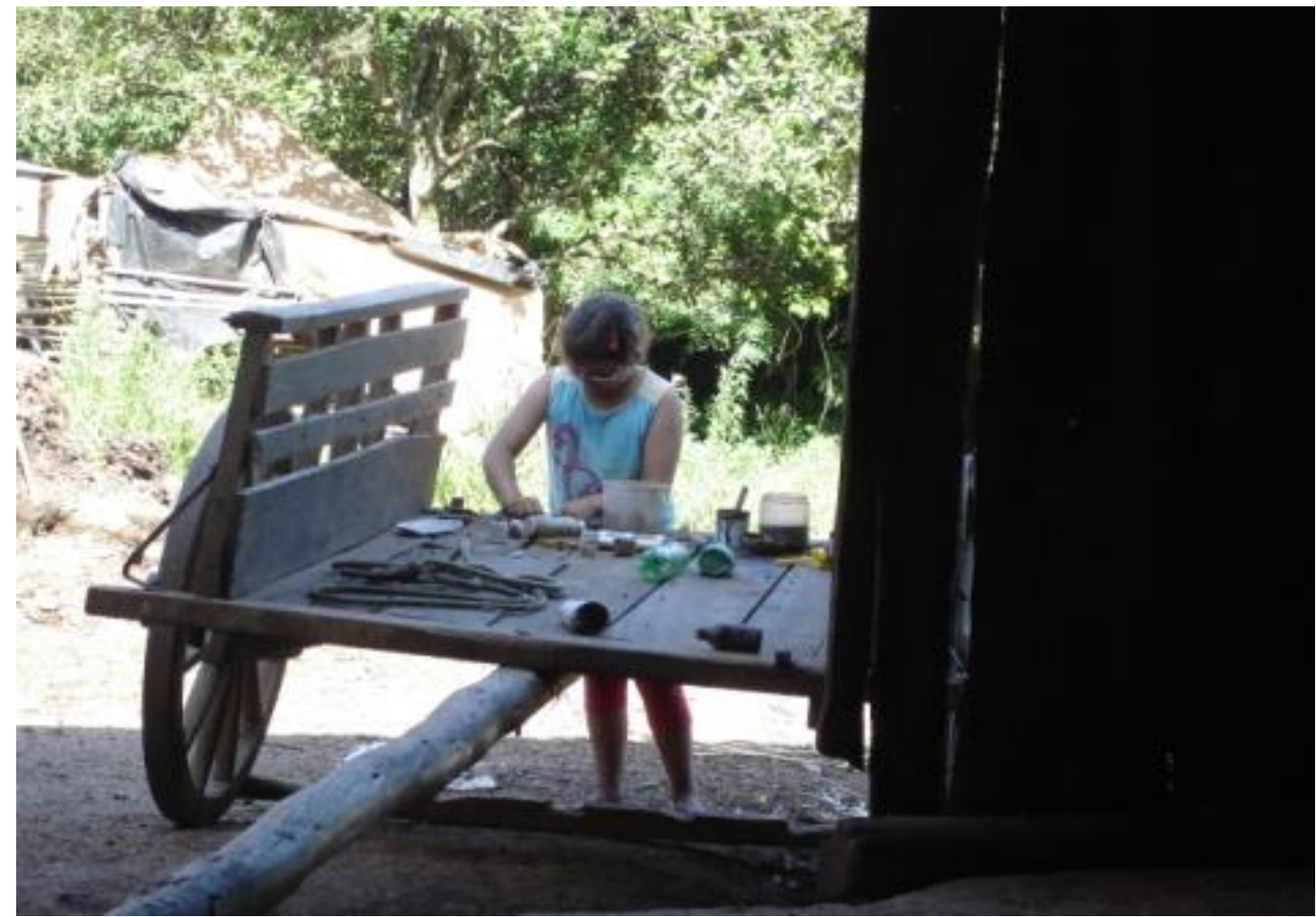

Infância rural: exercendo a ludicidade e criatividade para além das tecnologias como a TV e o celular. Rincão dos Maia, Canguçu/RS, 2011. Foto: Eliziane Nicolodi Francescato Ruiz.

\section{Dádivas}

O que circula nas relações entre as pessoas vai para além do bem material: são afetos, valores, vínculos, identidades... mas também angústias, medos, sofrimentos. Laços e nós, laços e abraços...

Com inspiração na importância que as sociabilidades demonstram ter no enfrentamento de problemas cotidianos do rural, foi no paradigma da dádiva (darreceber-retribuir), que encontramos o suporte teórico para compreender a forma com que os atores tecem e agem nas relações sociais, pois o enfrentamento de problemas e soluções que são construídas adquirem significado a partir de relações sociais.

Estas relações são eventos que não se dão no vazio, mas se constituem tendo como substrato e motivo a circulação de bens que atuam criando sociabilidades e ordenando os comportamentos em contextos concretos de existência humana. 


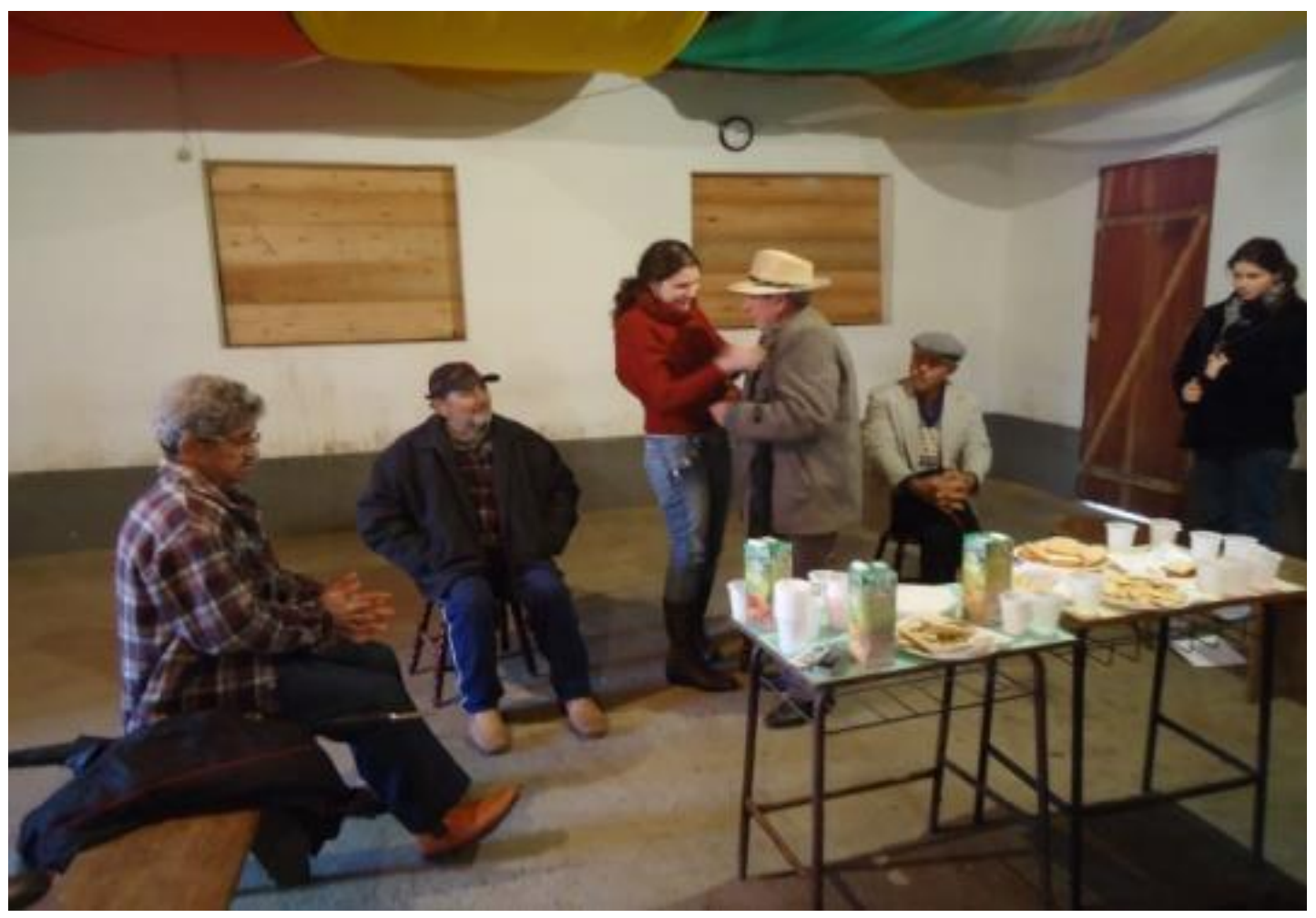

Dialogando sobre arranhaduras da masculinidade e saúde, a comida é sempre um motivo.... Localidade Rincão dos Maia, Canguçu/RS, 2011. Foto: Eliziane Nicolodi Francescato Ruiz.

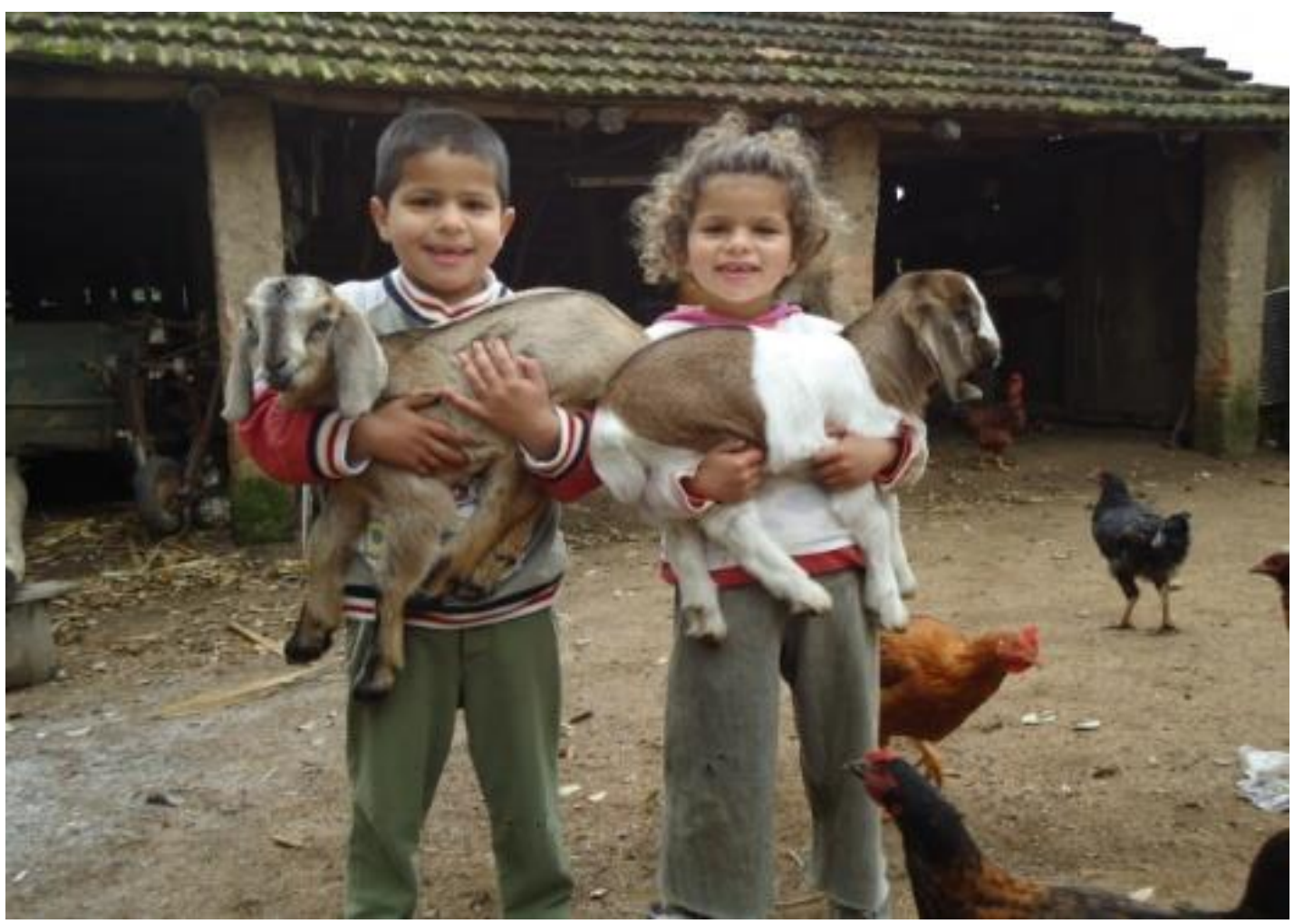

Criar e brincar na infância: renda e diversão. Localidade Rincão dos Maia, Canguçu/RS, 2011. Foto: Andréia Burille.

Iluminuras, Porto Alegre, v. 16, n. 40, p. 345-374, ago/dez, 2015. 
Tatiana Gerhardt, Roberto Verdum, Ana Carrion, Andreia Burille, Cristiane Riquinho, Eliziane Ruiz, Joana Cicconeto, Joannie Soares, Luciana Alcântara, Potiguara Paz e Vilma dos Santos

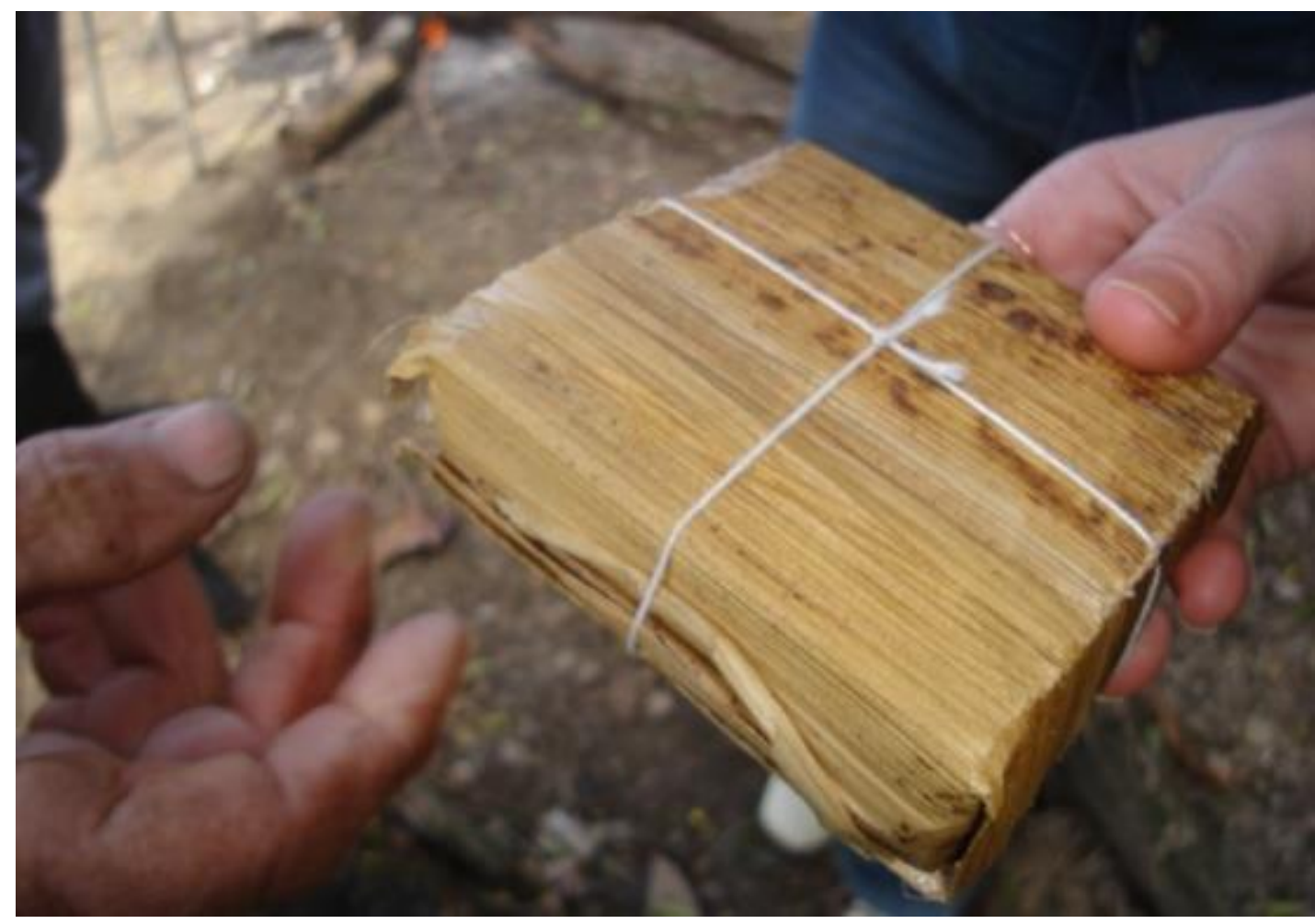

Compartilhando alimento e tradição e promovendo vínculos.

Santana da Boa Vista/RS, 2008. Foto: Cristiane Tonezer e Luciana Alcântara.

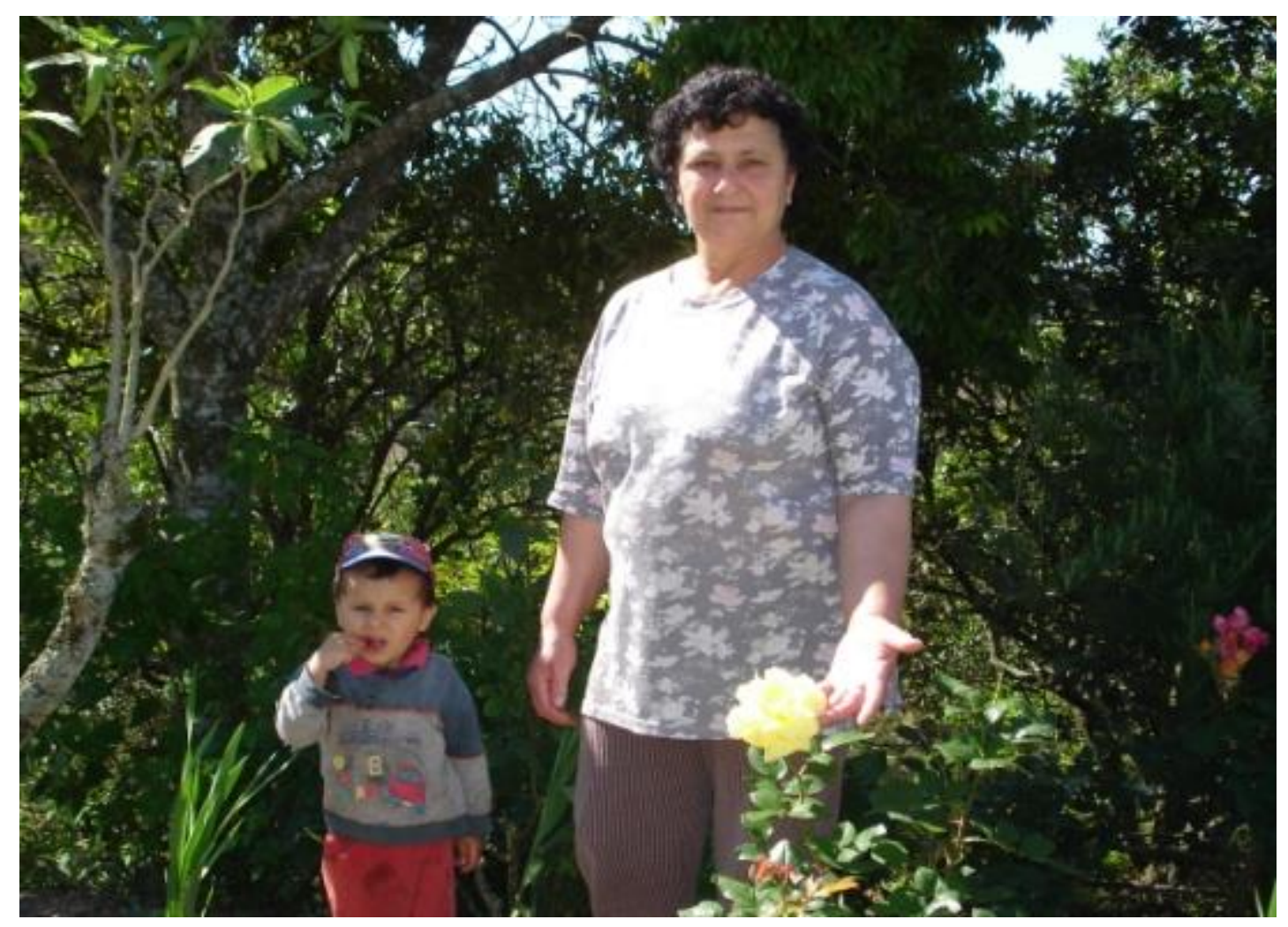

Os jardins das casas são dádivas que florescem pelas mãos das pessoas. Localidade Rincão dos Maia, Canguçu/RS, 2011. Foto: Eliziane Nicolodi Francescato Ruiz. 


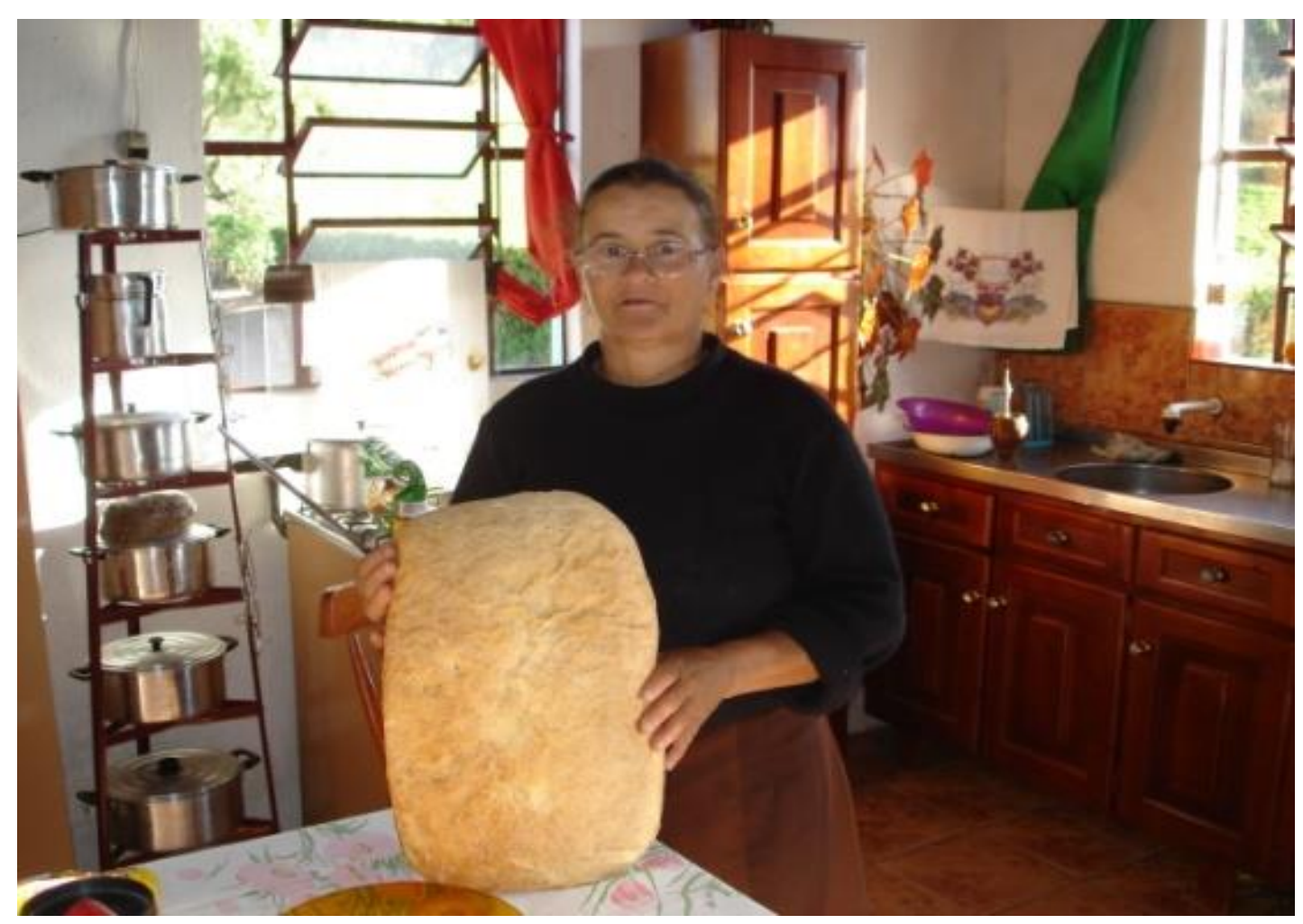

Saber fazer o pão: conhecendo as massas e as maçãs...

Localidade Rincão dos Maia, Canguçu/RS, 2011. Foto: Eliziane Nicolodi Francescato Ruiz.

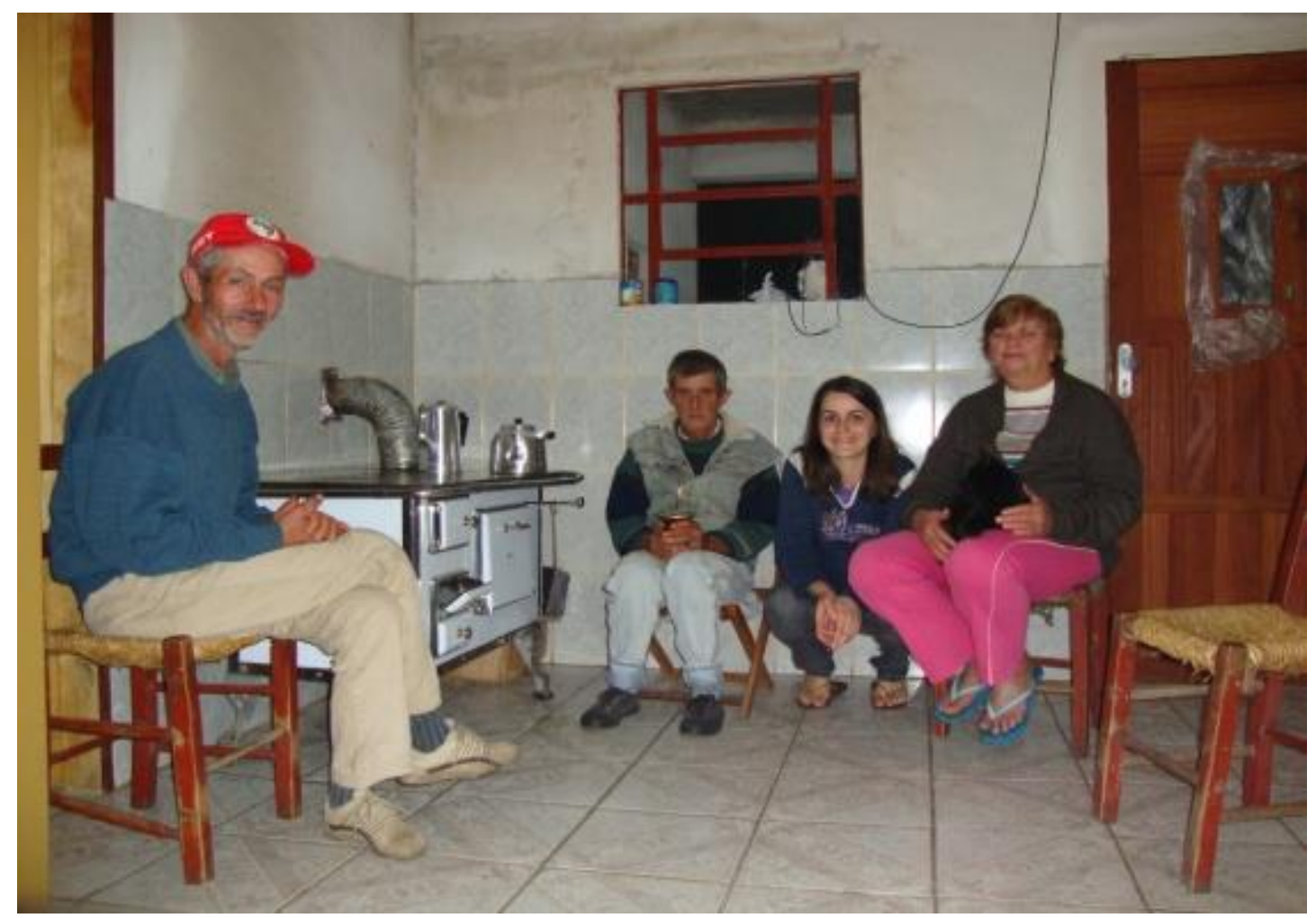

Chimarrão, fogão, lenha: para uma aquecida conversa.

Assentamento Boa Fé, Localidade Passo do Lourenço, Canguçu/RS, 2010. Foto: Joana Cicconeto. 


\section{Patrimônio cultural}

Histórias de vidas, histórias de amor e fé, lembranças de gente do passado, de apostas no futuro, na mansidão dos campos e na solidão da espera por tempos melhores...

O ato de contemplar, enquadrar e registrar a natureza e as pessoas não é natural, ou seja, o ato de olhar é resultante de um patrimônio cultural que elaborou essa contemplação e que confere significações e valores ao registro fotográfico. A cultura não deixa de ser a forma como as pessoas transformam a materialidade do mundo cotidiano num mundo de símbolos e representações. Assim, as representações podem ser consideradas como uma forma de elaboração humana, através das culturas, nas quais as ideias, os sentimentos e as expressões se constituem em um patrimônio, capaz de ser reproduzido, acumulado e reinventado.

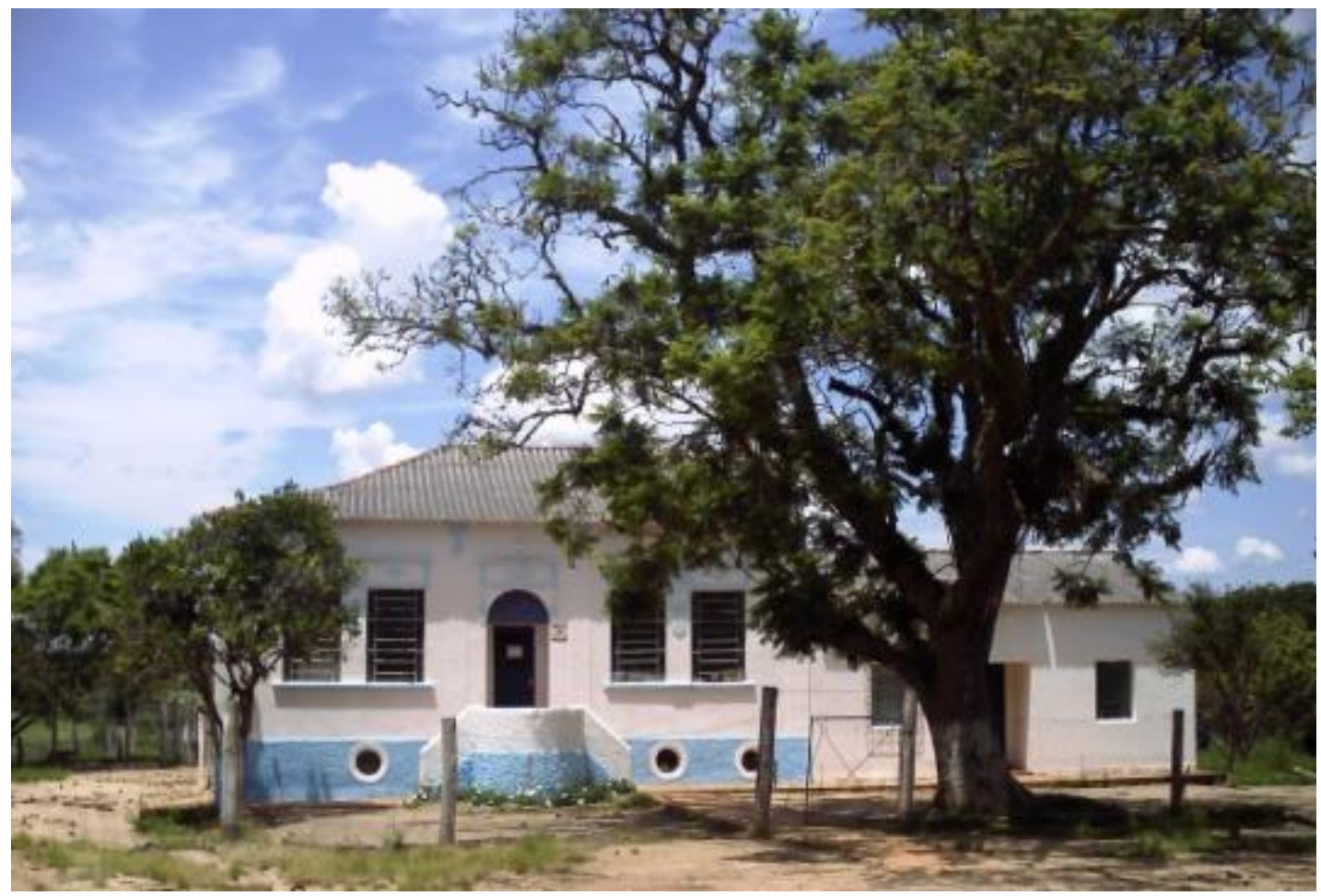

História e saberes: preservando patrimônios.

Assentamento Segredo Farroupilha, Encruzilhada do Sul/RS, 2009. Foto: Joannie Fachinelli Soares. 


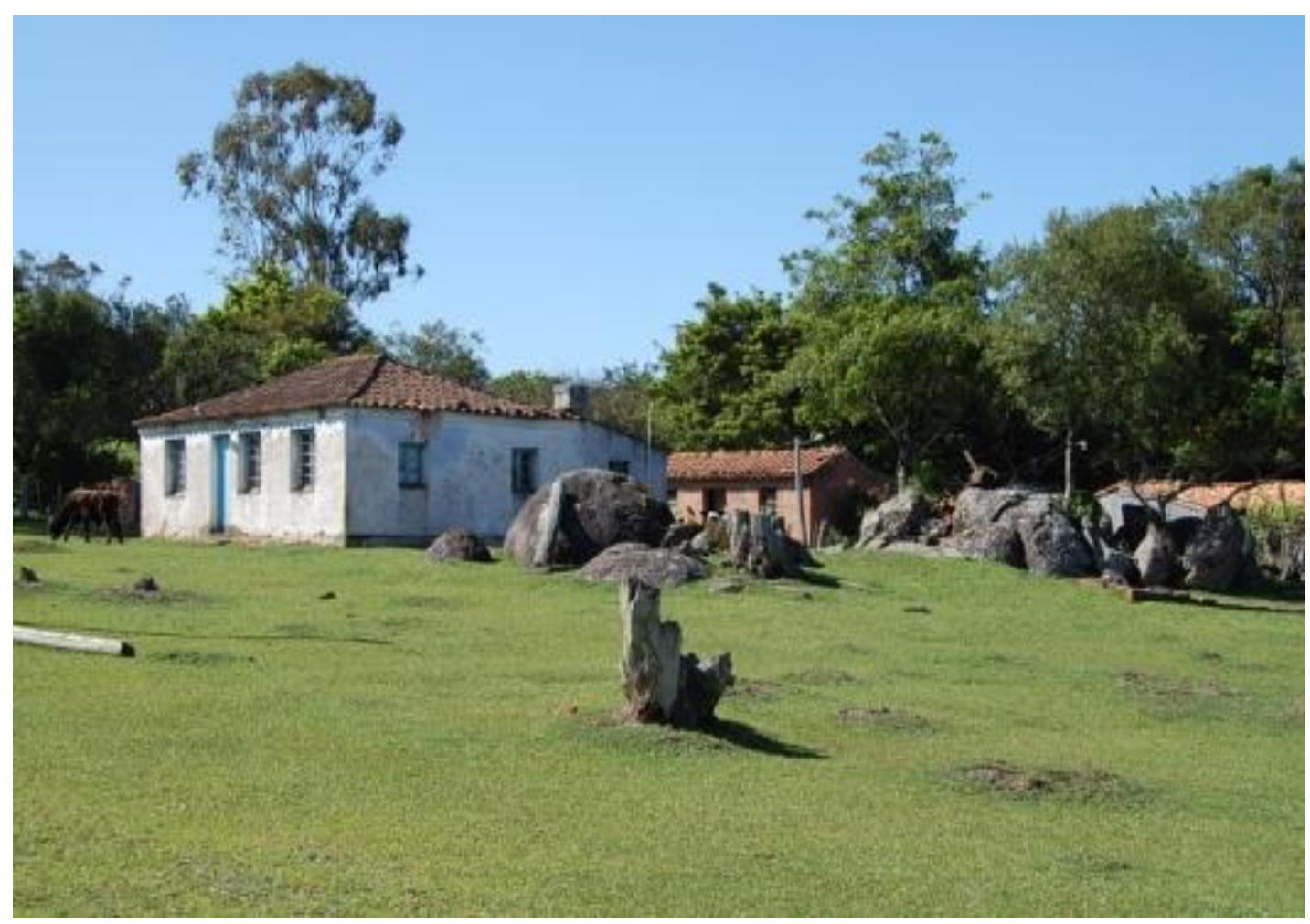

O casario típico e a pecuária tradicional extensiva ancorados nos afloramentos de rochas graníticas modelam a paisagem rural. Canguçu/RS, 2012. Foto: Roberto Verdum.

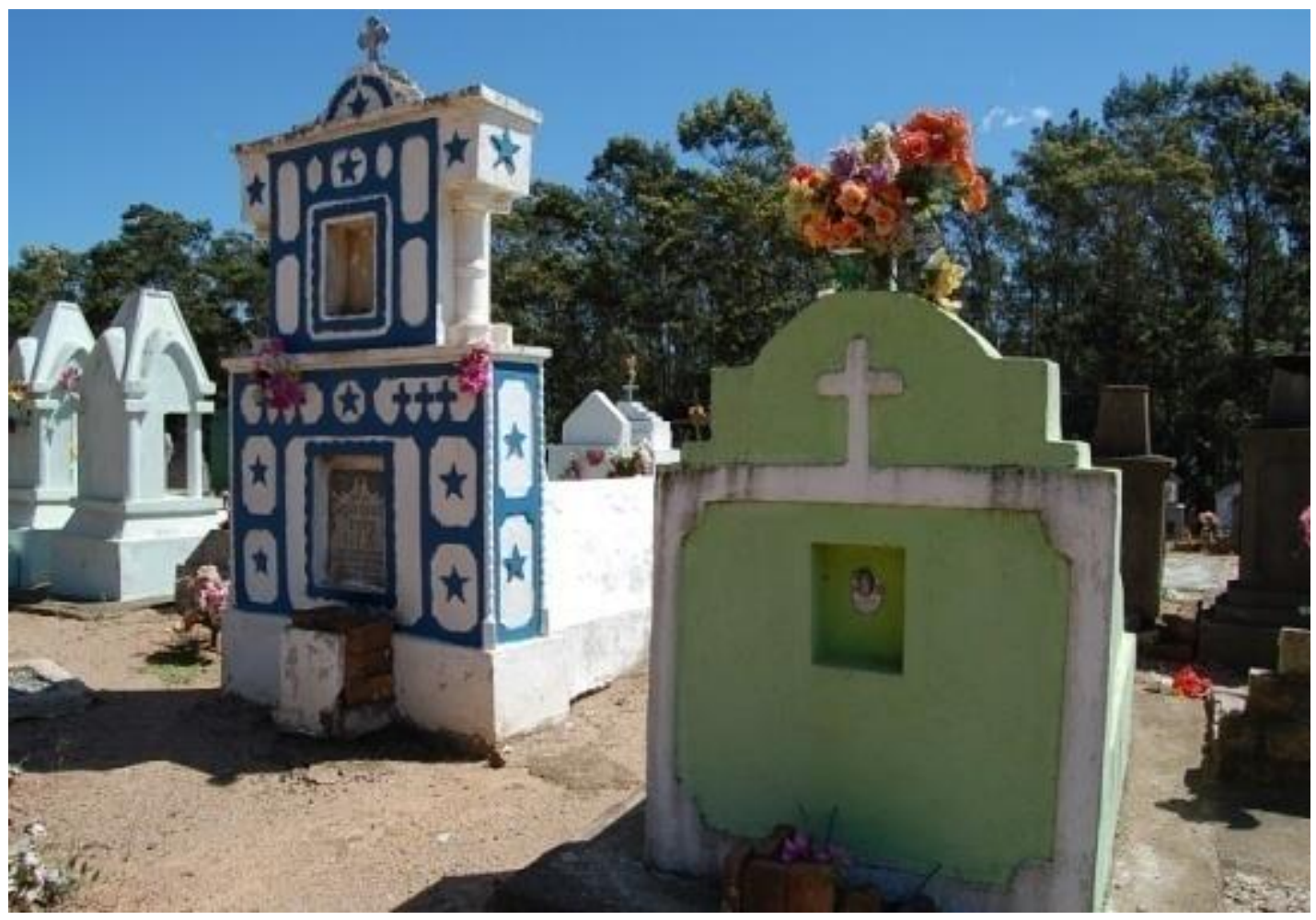

Cemitérios: expressões de respeito e arte.

Canguçu/RS, 2012. Foto: Roberto Verdum. 
Tatiana Gerhardt, Roberto Verdum, Ana Carrion, Andreia Burille, Cristiane Riquinho, Eliziane Ruiz,

Joana Cicconeto, Joannie Soares, Luciana Alcântara, Potiguara Paz e Vilma dos Santos

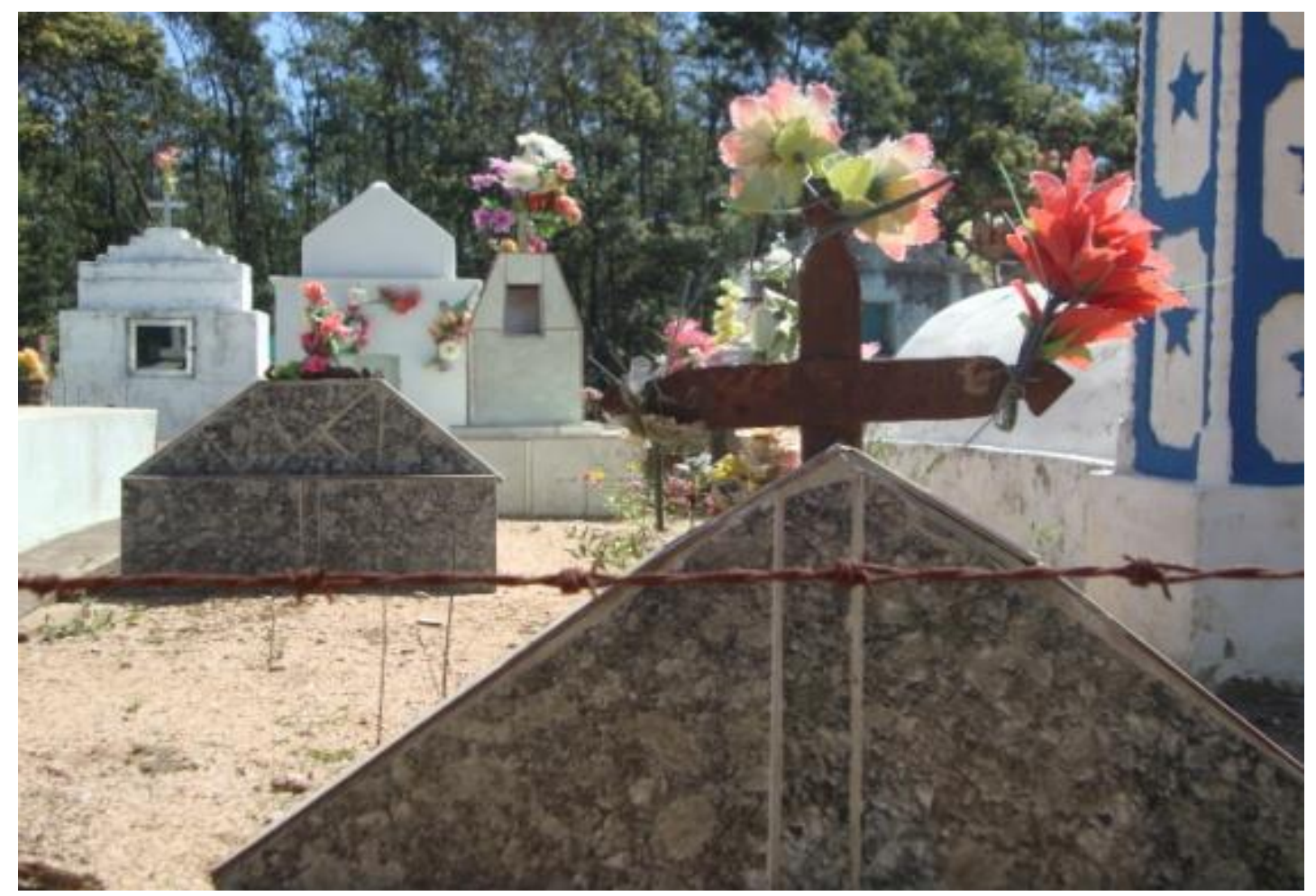

Flores, natureza e o ciclo da vida.

Canguçu/RS, 2012. Foto: Ana Carrion.

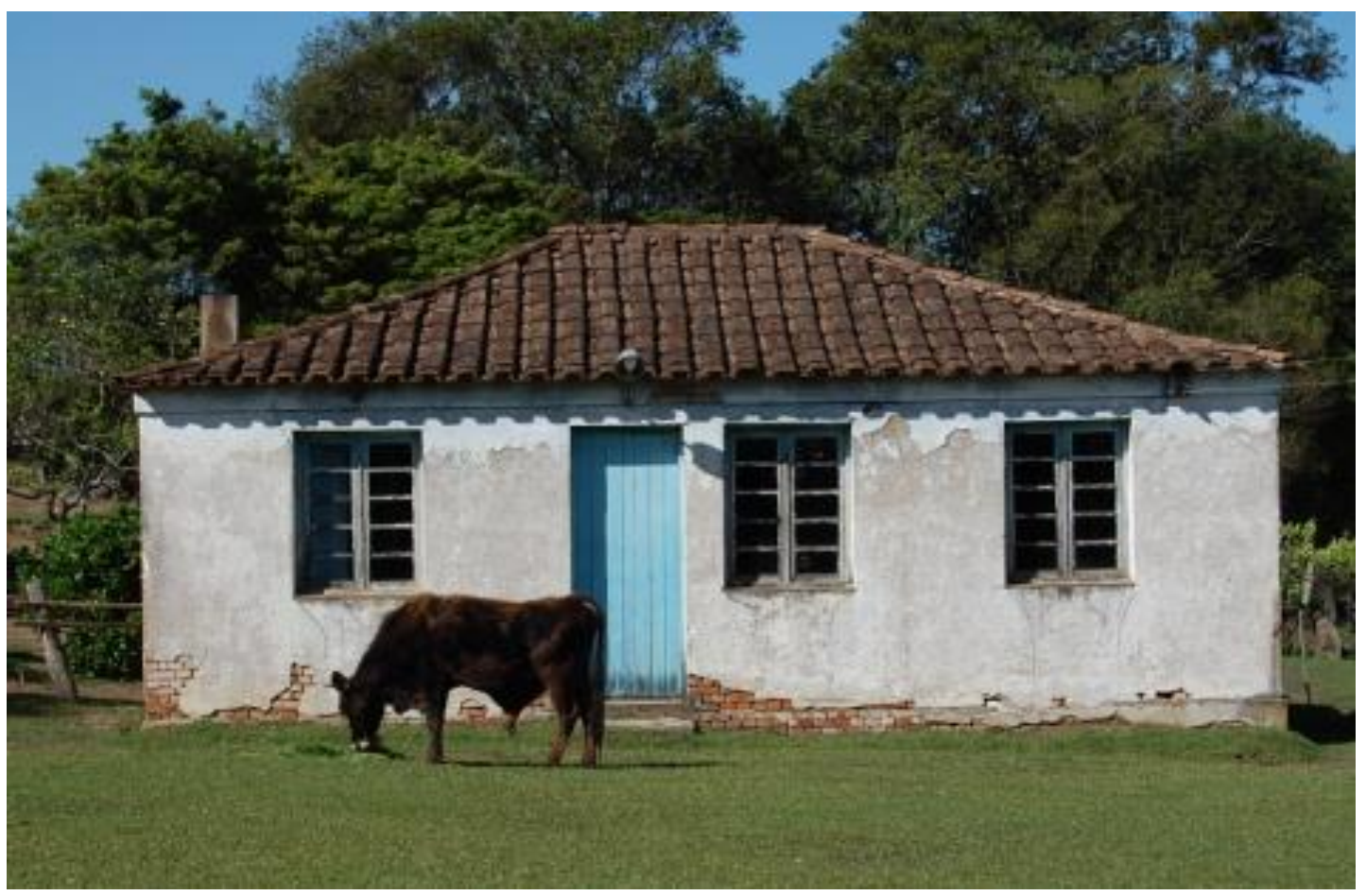

O casario típico e pecuária tradicional extensiva: rugosidades que persistem.

Canguçu/RS, 2012. Foto: Roberto Verdum. 


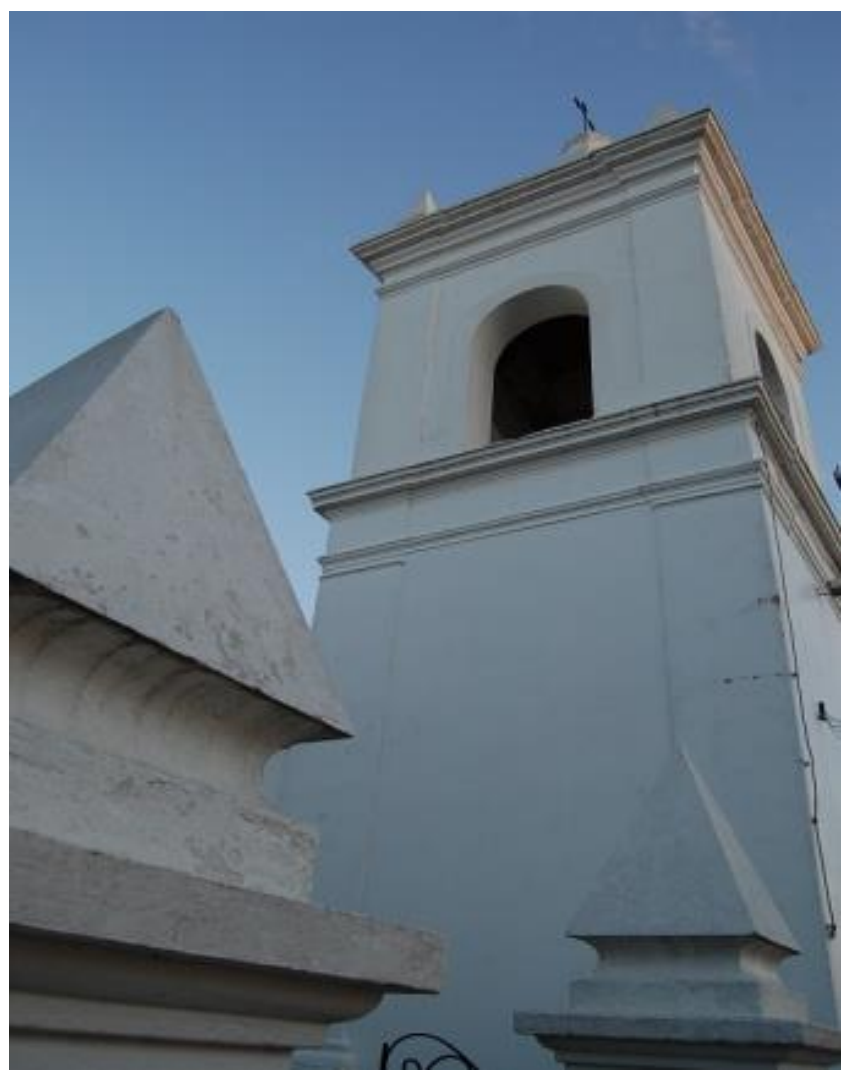

A Igreja Matriz: preservando traços do período colonial. Canguçu/RS, 2012. Foto: Roberto Verdum.

\section{Produção e trabalho}

Aqui se produz, o trabalho é intenso e o tempo sem fim! Plantar, germinar, colher o fruto aninhado na terra e fecundado pelo suor!

As ações humanas, através do trabalho, correspondem ao processo social que gera produtos, ou seja, objetos que demarcam uma temporalidade e que estão em constante transformação. Registrar as ações e os objetos humanos gerados pelo trabalho representa a busca de uma explicação da realidade e de sua transformação. O trabalho humano representa o híbrido entre natureza e sociedade, composto de formas, conteúdos, funções e objetos. É o resultado das condições históricas de transformação do espaço geográfico. Na ação do trabalho há a unidade espaço-temporal, sendo ele, cada vez mais técnico e artificializado. No entanto, ainda se pode encontrar e registrar criações do trabalho que poderiam ser consideradas do passado, mas que criam e recriam seu próprio tempo. 


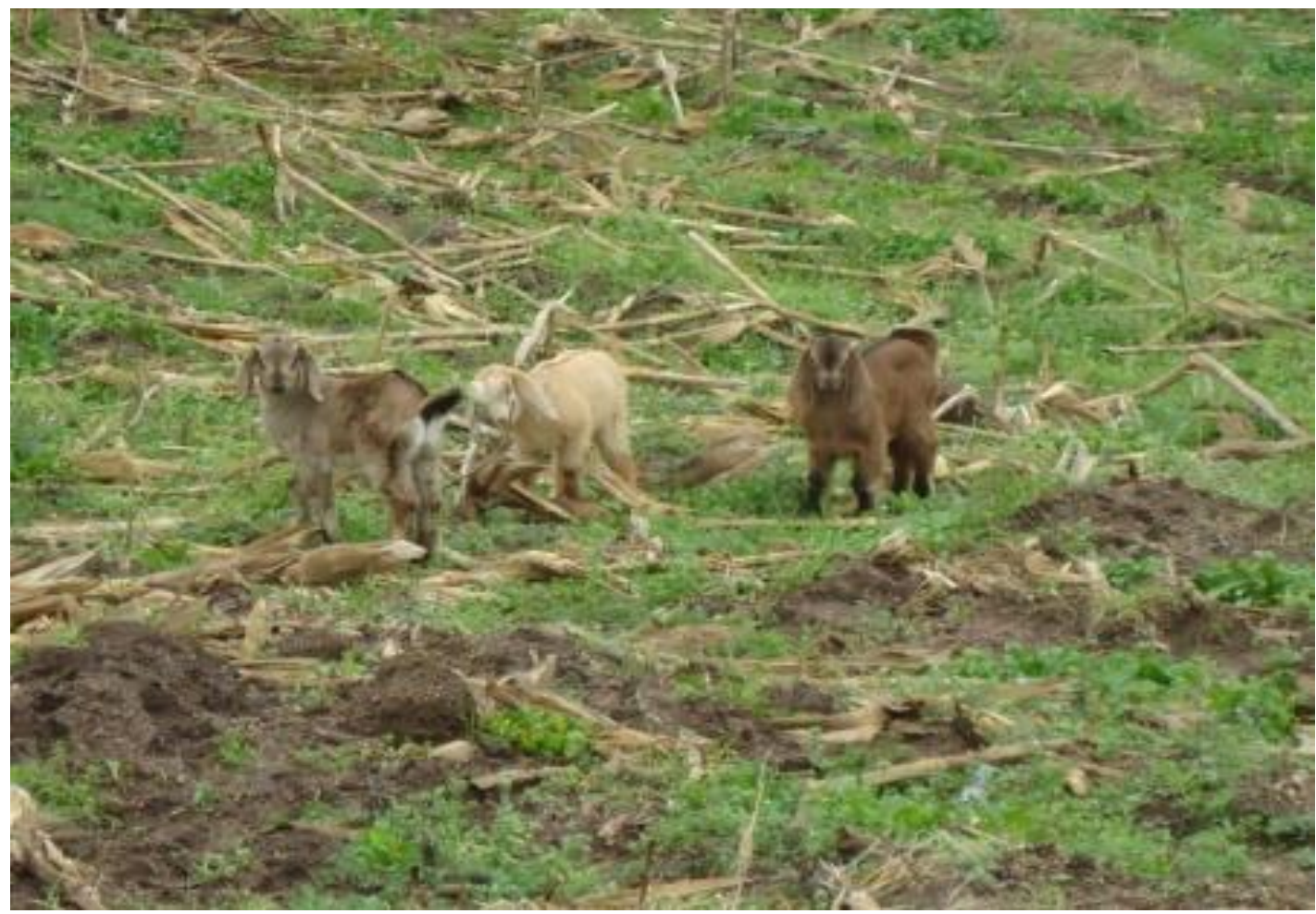

Nos caminhos da pesquisa: os animais e o sustento das famílias. Localidade Rincão dos Maia, Canguçu/RS, 2012. Foto: Andréia Burille.

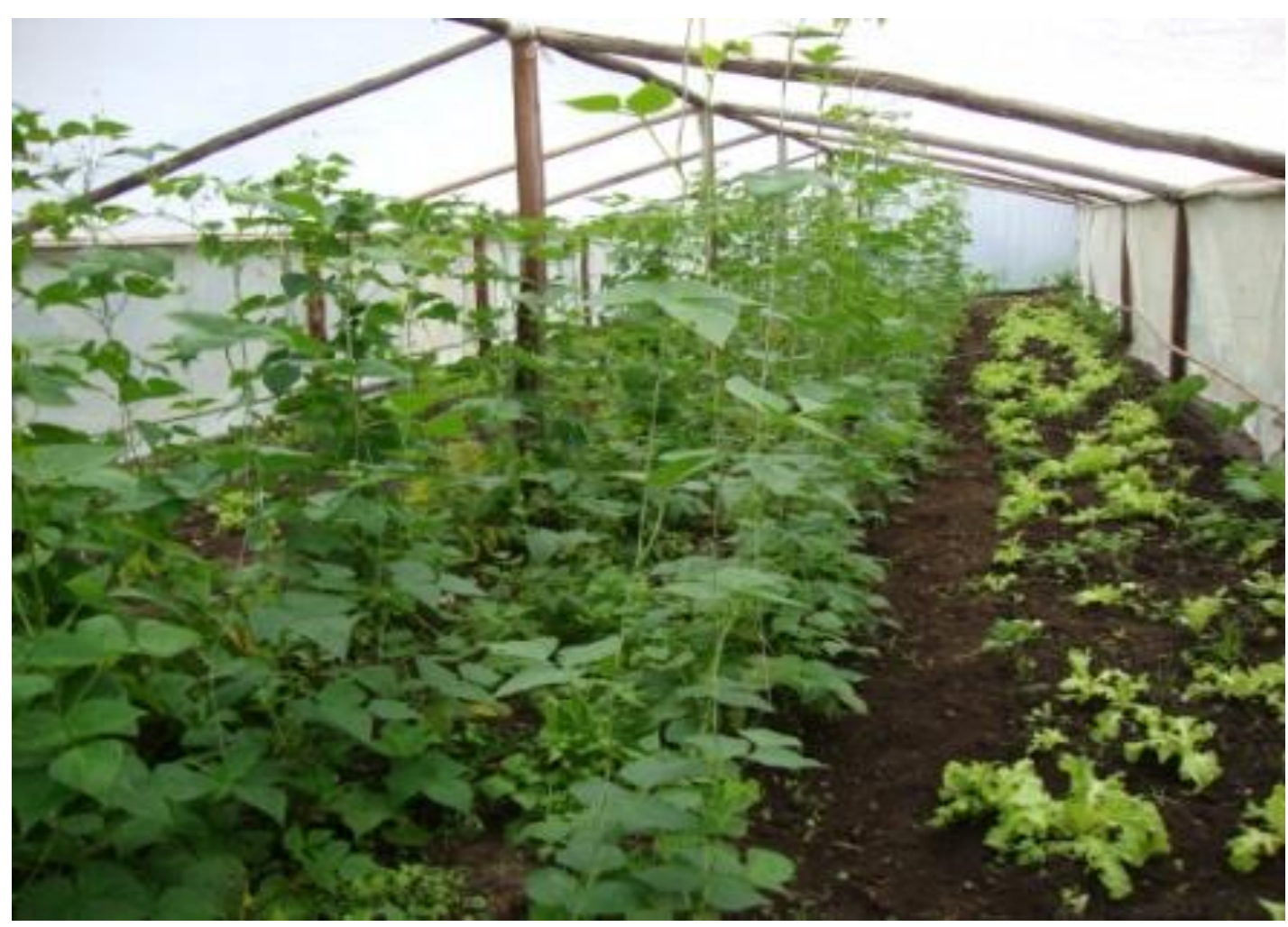

Tecnologias de produção e sustentabilidade. Localidade Remanso, Canguçu/RS, 2010. Foto: Joana Cicconeto. 


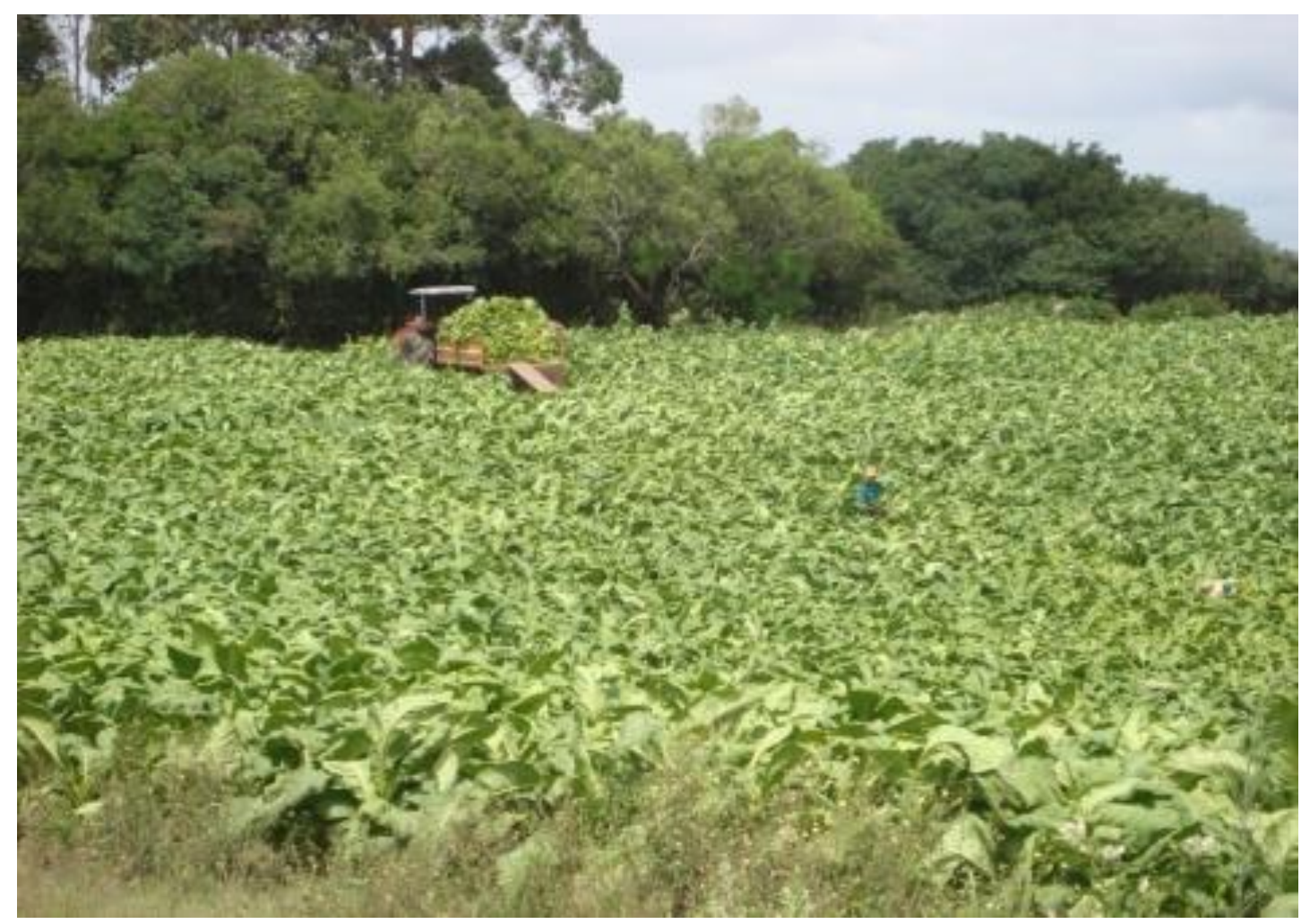

A colheita do fumo: mudanças de práticas e modos de produção. Canguçu/RS, 2009. Foto: Francis dos Santos.

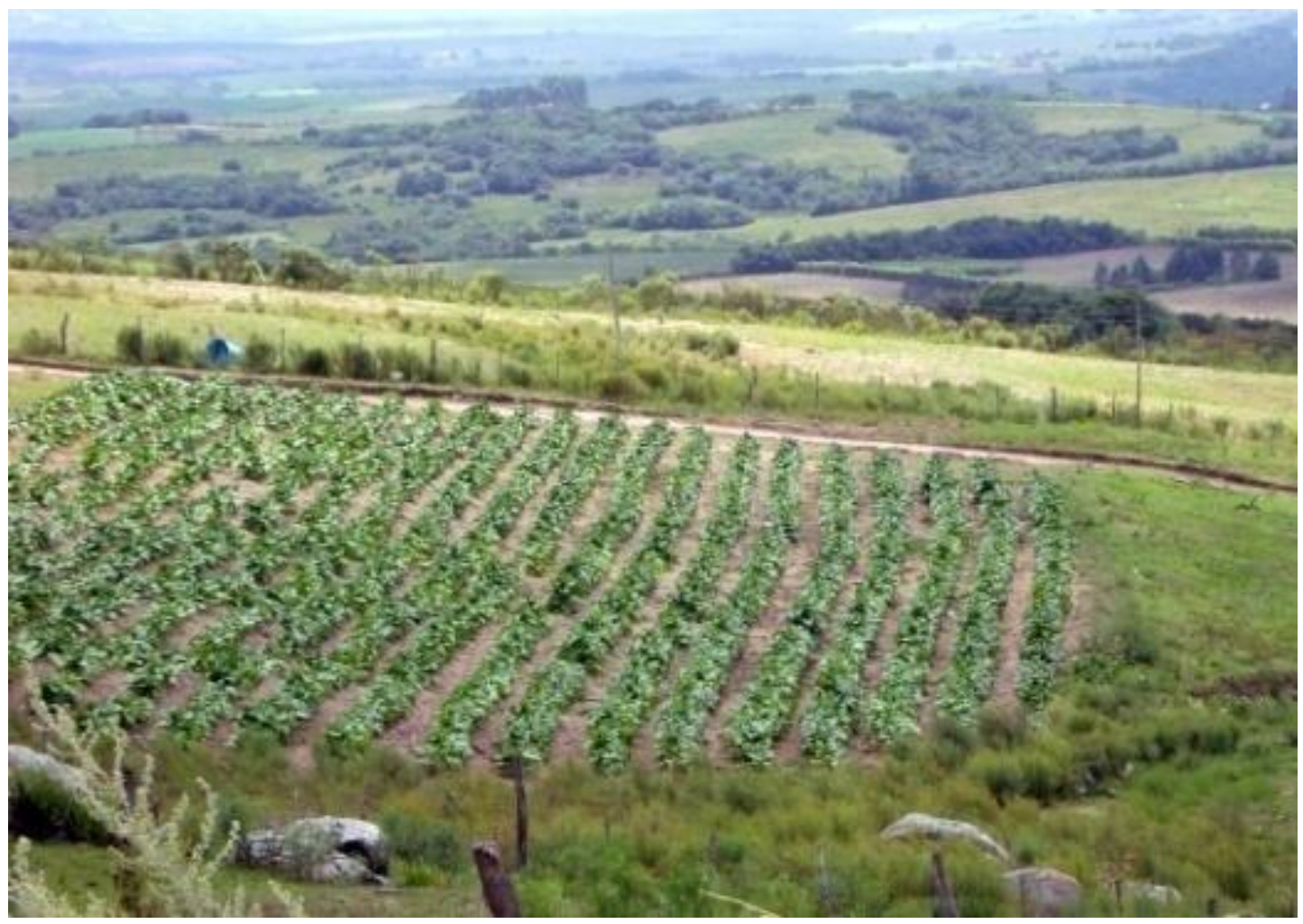

Fumo: mudanças de práticas e modos de produção.

Canguçu/RS, 2009. Foto: Francis dos Santos. 


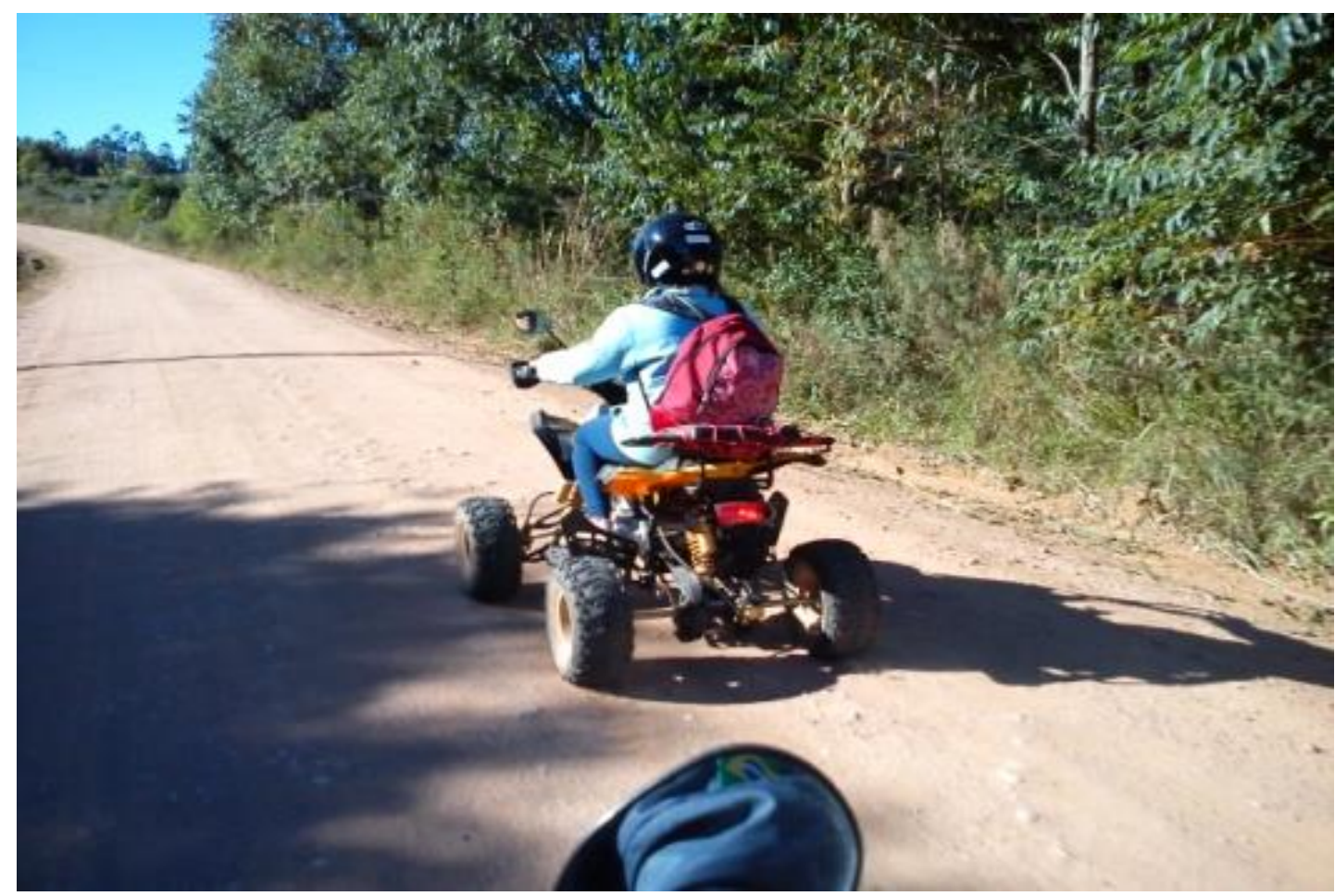

Transportando saúde: visita domiciliar de agente comunitária de saúde. Santa Auta, Camaquã/RS, 2012. Foto: Potiguara de Oliveira Paz.

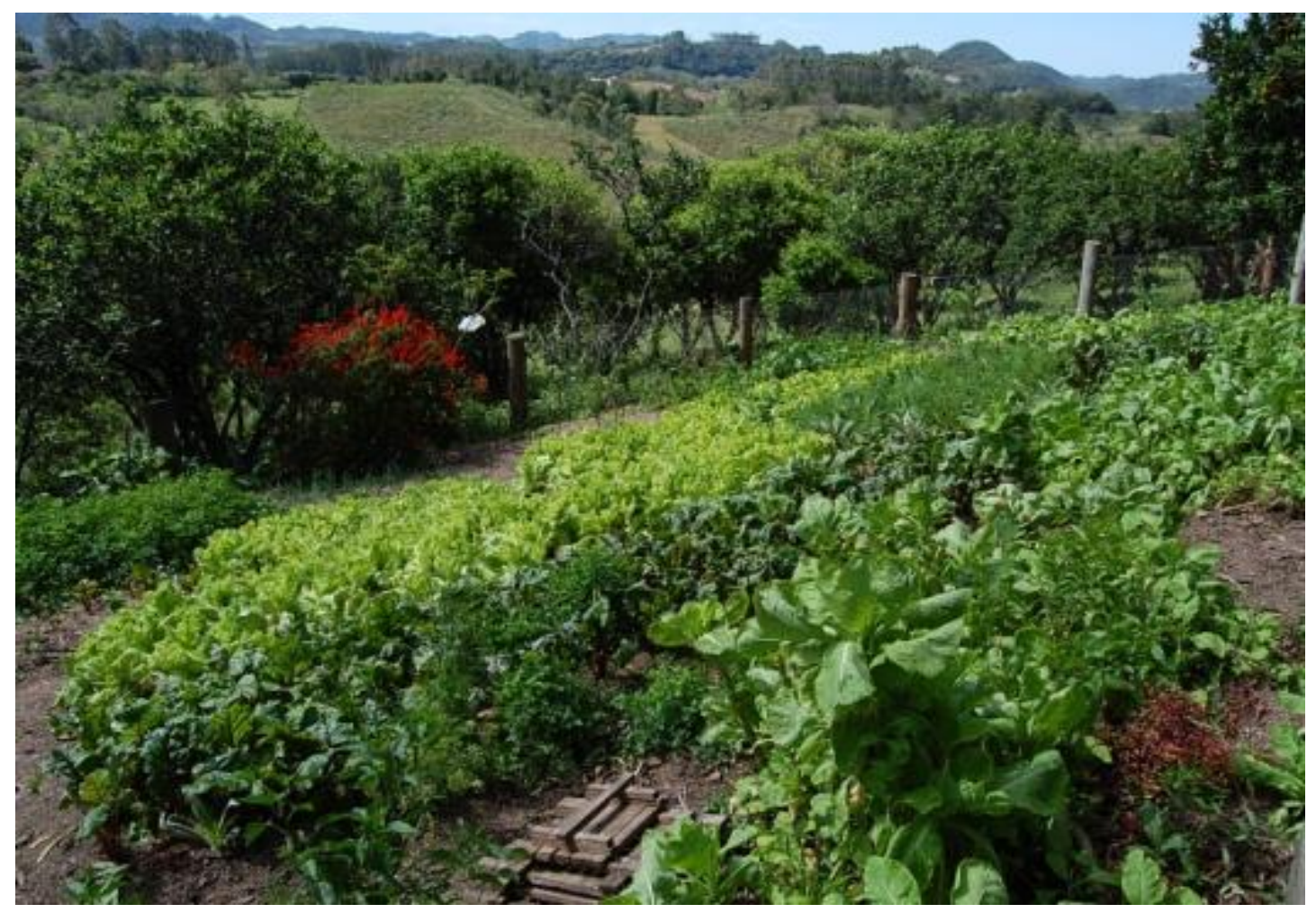

Garantindo a segurança alimentar: produção orgânica de legumes e verduras. Canguçu/RS, 2012. Foto: Roberto Verdum. 


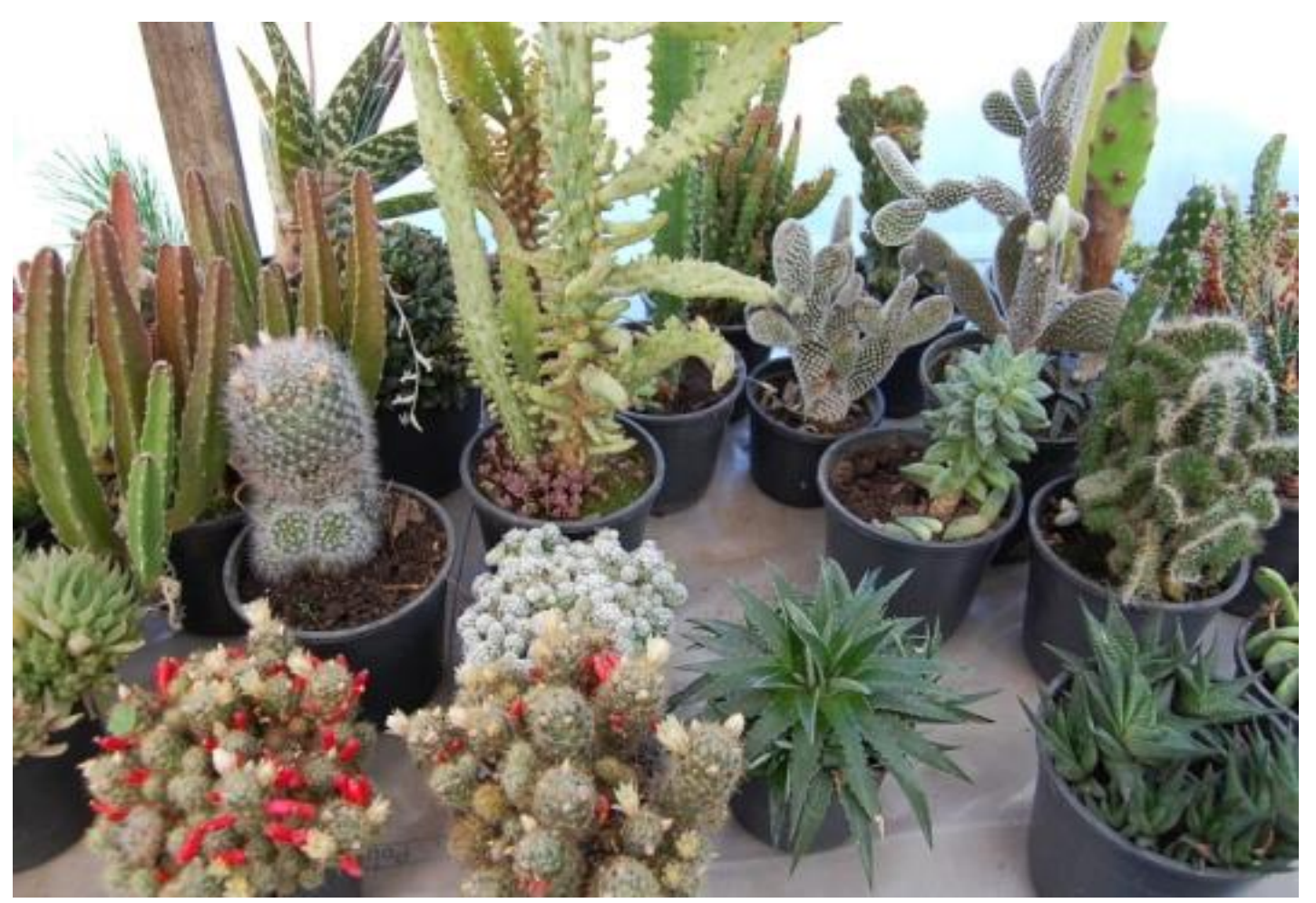

O cultivo de espécies de cactos: renda, valoração e preservação das espécies locais. Canguçu/RS, 2012. Foto: Roberto Verdum.

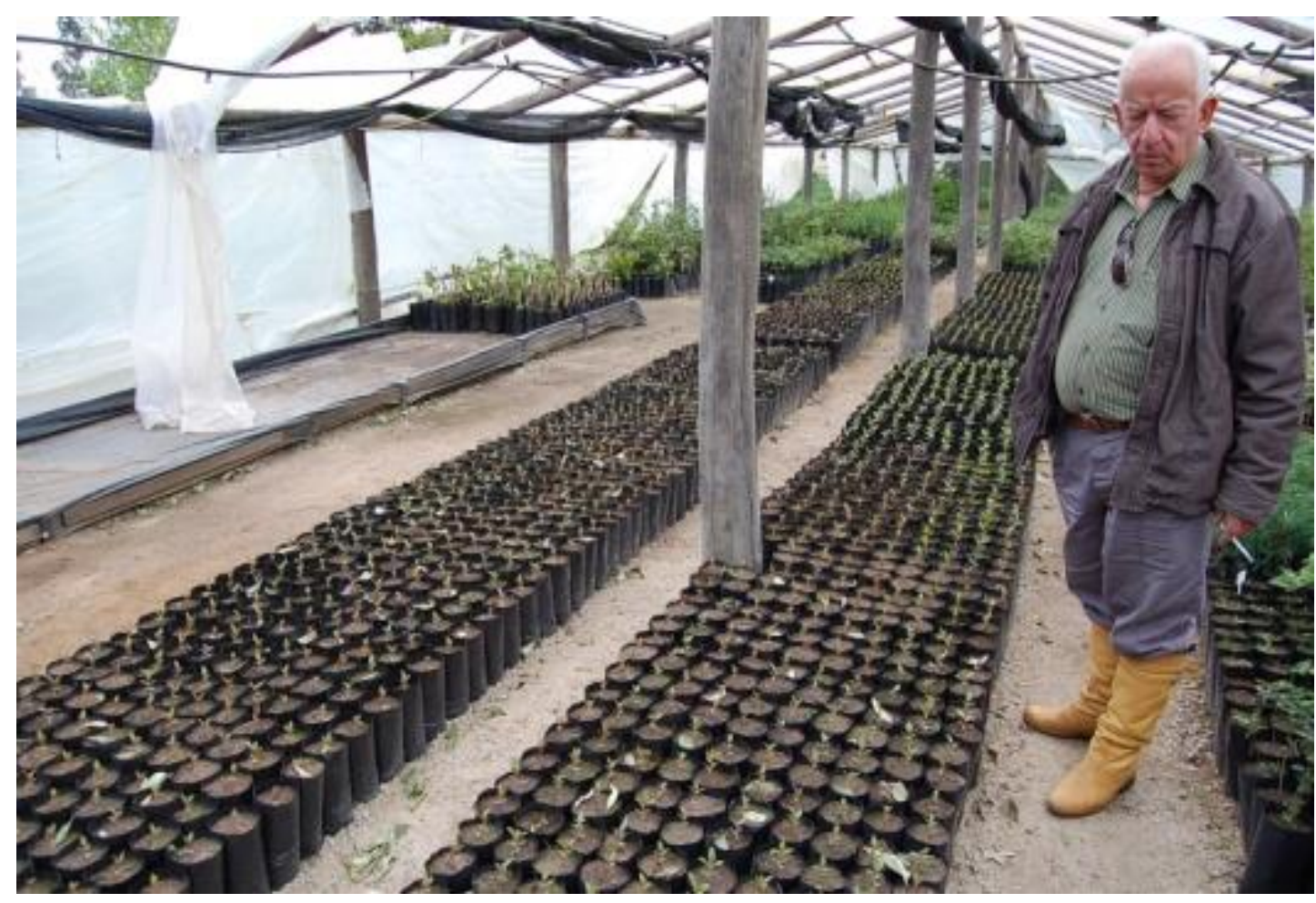

Espécies ornamentais, frutíferas, nativas e exóticas: o horto municipal construindo jardins e compensado danos ambientais. Canguçu/RS, 2012. Foto: Roberto Verdum. 
Tatiana Gerhardt, Roberto Verdum, Ana Carrion, Andreia Burille, Cristiane Riquinho, Eliziane Ruiz, Joana Cicconeto, Joannie Soares, Luciana Alcântara, Potiguara Paz e Vilma dos Santos

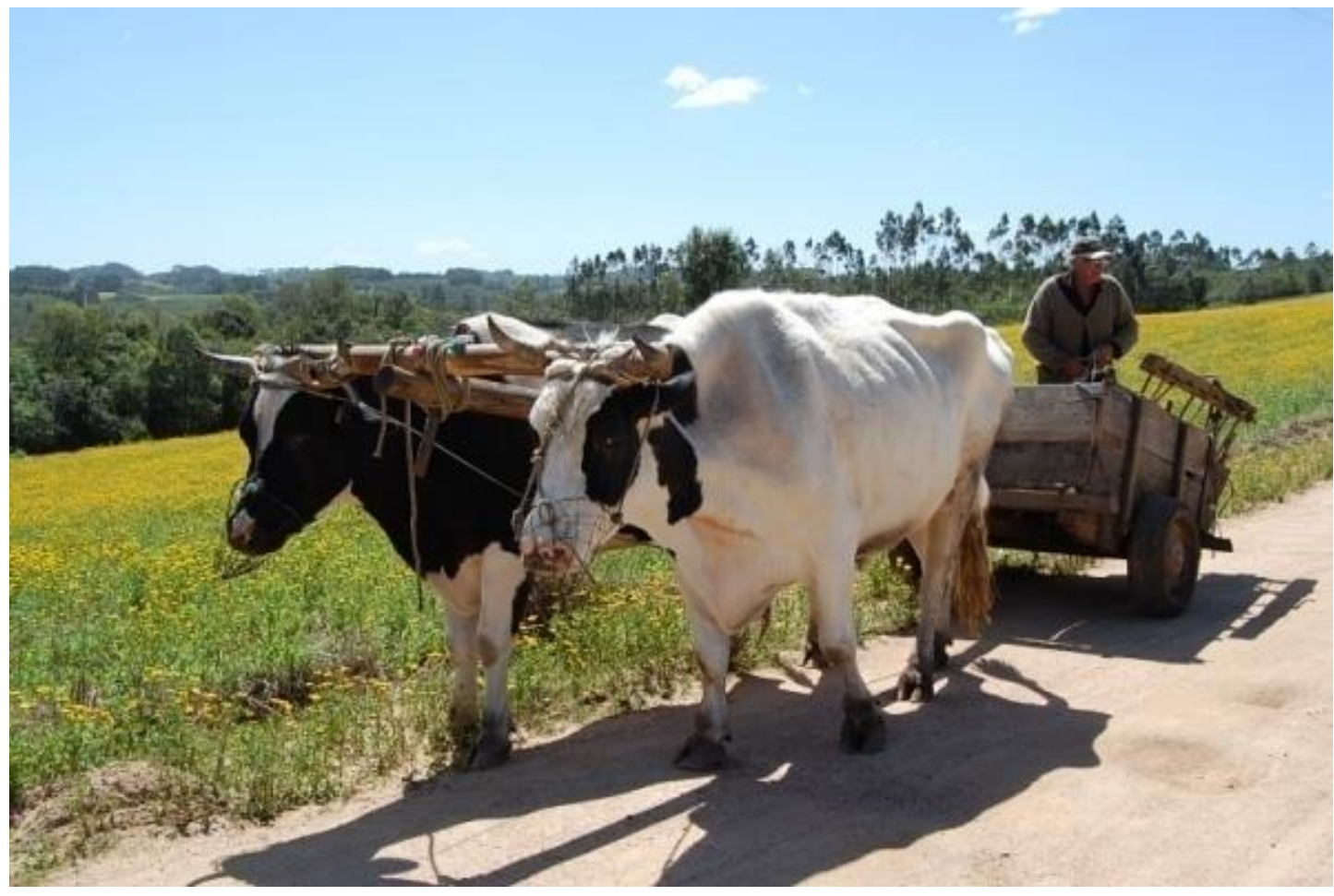

Elementos da agricultura familiar em relevo acidentado: a tração animal bovina trabalhando o solo. Canguçu/RS, 2012. Foto: Roberto Verdum.

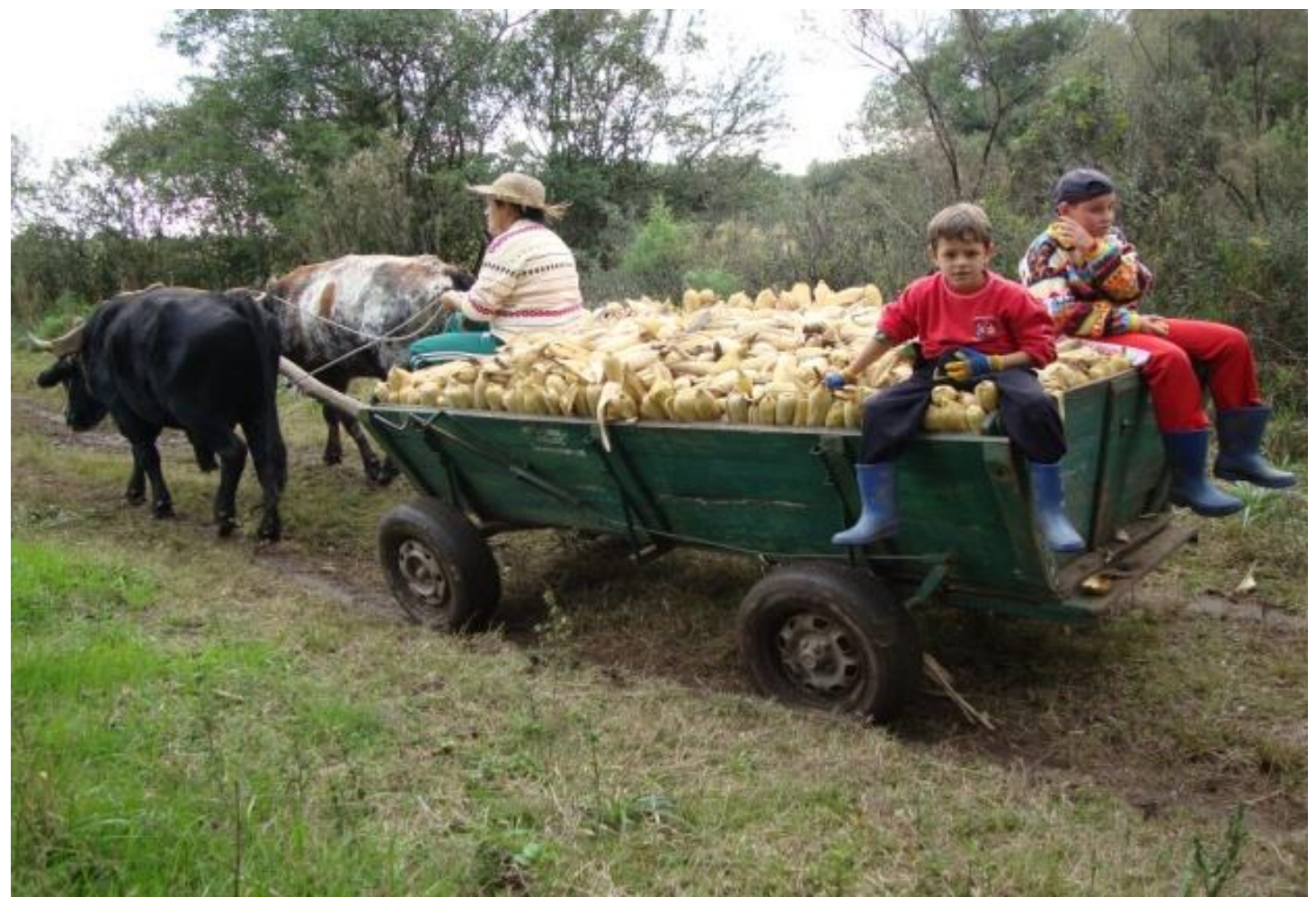

Colheita e cultivo do conhecimento para diferentes gerações. Assentamento Herdeiros na Luta. Canguçu/RS, 2010. Foto: Joana Cicconeto.

Iluminuras, Porto Alegre, v. 16, n. 40, p. 345-374, ago/dez, 2015. 


\section{Considerações Finais: Trilhando caminhos...}

A narrativa visual construída pelas imagens de Paisagens, pessoas e vidas rurais dão visibilidade para a expressão de um espaço e um modo de vida, e representam o olhar dos pesquisadores ao "lerem as imagens" e montarem sua sequencia a partir da interpretação do seu significado. Os significados das sequencias foram uma criação oriunda das reflexões coletivas dos pesquisadores e que vão sendo revelados ao receptor, à medida que ele a decodifica como um todo, num único bloco informativo. $\mathrm{O}$ "não-dito" em texto tem o propósito de deixar ao receptor a possibilidade de interação e de interpretação, para além da indução e intencionalidade dada na leitura por meio do trajeto estabelecido pelos pesquisadores.

A proposta de narrativa permitiu refletir acerca da possibilidade da imagem fotográfica poder se apresentar como uma narrativa visual, capaz de problematizar a informação visual para além de seu aspecto meramente documental e, desse modo, ser um espaço de experimentação da linguagem fotográfica, e como tal, permanece ainda em aberto...

\section{Referências}

ALCÂNTARA, L. R. Idosos Rurais de Santana da Boa Vista/RS: condições de saúde e trajetórias terapêutica. Dissertação de Mestrado - 2009, EENF.

ALMEIDA, J.; GERHARDT, T.; MIGUEL, L. de A.; MIELITZ NETTO, C. G. A.; VERDUM, R.; BECK, F. de L.; ZANONI, M. M. Por caminhos tortuosos da interdisciplinaridade: uma experiência de pesquisa acadêmica no sul do Brasil. In: JACOBI, Pedro; FERREIRA, Lúcia da Costa. (Org.). Diálogos em ambiente e sociedade no Brasil. São Paulo: Annablume, v. 1, p. 251-278, 2006.

ALMEIDA, J. Situações de vida e saúde de idosos do meio rural do município de Arambaré. Dissertação de Mestrado - 2004, EENF.

BECK, F. de L.; ALMEIDA, J.; VERDUM, R.; ZANONI, M. M.; MIELITZ NETO, C. G. A.; GERHARDT, T. E.; RAYNAUT, C.; LOPES, M. J.; MIGUEL, L. de A.; SOUZA, G. C. de. Construção de problemática interdisciplinar na pós-graduação. In: PHILIPPI Jr, Arlindo; SILVA NETO, Antonio. (Org.). Interdisciplinaridade em ciência, tecnologia e inovação. [finalista no $53^{\circ}$ Prêmio Jabuti na categoria Educação]. 1ed. Barueri - SP: Editora Manole, v. 1, p. 263-297, 2011.

BURILLE, A. Itinerários terapêuticos em situação de adoecimento crônico: homens, cuidado e arranhaduras da masculinidade. 2012. Dissertação (Mestrado em Programa de Pós-Graduação em Enfermagem) - Universidade Federal do Rio Grande do Sul.

CARRION, A. A. Potencial de plantas ornamentais para o desenvolvimento rural no município de Canguçu/RS. 2013. Dissertação (Mestrado em Desenvolvimento Rural) - Universidade Federal do Rio Grande do Sul, Coordenação de Aperfeiçoamento de Pessoal de Nível Superior. CICCONETO, J. A diversidade e a emergência da agricultura familiar ecológica em Canguçu $(R S)$ : percepções, estratégias e discussões. 2011. Dissertação (Mestrado em Desenvolvimento 
Rural) - Universidade Federal do Rio Grande do Sul, Coordenação de Aperfeiçoamento de Pessoal de Nível Superior.

COSTA, M. C. $O$ visivel e o invisivel na inconsciência do óbvio: agendas públicas municipais, práticas profissionais de saúde e a violência contra mulheres rurais. Tese de Doutorado - 2012, EENF. Orientadora: Marta Julia Marques Lopes.

COTRIM, M. Pecuária Familiar na região da Serra do Sudeste do Rio Grande do Sul: um estudo sobre a origem e a situação sócio-agroeconômica do 'pecuarista familiar' no município de Canguçu/RS. 2003. Dissertação (Mestrado em Desenvolvimento Rural) - Universidade Federal do Rio Grande do Sul, Coordenação de Aperfeiçoamento de Pessoal de Nível Superior.

FACHINELLI, J. S. Biografias de gravidez e maternidade na adolescência em assentamentos Rurais de Encruzilhada do Sul - RS. Dissertação de Mestrado - 2009, EENF.

FERREIRA, J. R. Evolução e Diferenciação dos Sistemas Agrários do Município de Camaquã/RS: uma análise da agricultura e suas perspectivas de desenvolvimento. 2001. Dissertação (Mestrado em Desenvolvimento Rural) - Universidade Federal do Rio Grande do Sul, Coordenação de Aperfeiçoamento de Pessoal de Nível Superior.

GERHARDT, T. E.; MIGUEL, L. de A.; VERDUM, R.; BECK, F. de L.; ALMEIDA, J.; MIELITZ NETTO, C. A. G.; LOPES, M. J.; RAYNAUT, C.; ZANONI, M. M. Crônica de uma discussão teórica interdisciplinar sobre noções e conceitos polissêmicos no tema do desenvolvimento rural. In: PHILIPPI Jr, Arlindo; FERNANDES, Valdir. (Org.). Práticas da interdisciplinaridade no ensino e na pesquisa. 1ed. São Paulo: Manole, 2014, v. 1, p. 1-16.

LIMA, M. C. R. Fluxos de utilização de serviços hospitalares: análise do perfil das internações e mobilidade de usuários em municípios da Metade Sul do RS à luz da regionalização. 2010. Dissertação (Mestrado em Programa de Pós-Graduação em Enfermagem) - Universidade Federal do Rio Grande do Sul.

LIMA, M. I. F. Paisagem e Sistemas Agrários de São Lourenço do Sul, RS. 2006. Dissertação (Mestrado em Desenvolvimento Rural) - Universidade Federal do Rio Grande do Sul, Coordenação de Aperfeiçoamento de Pessoal de Nível Superior.

OLIVEIRA, A. Formas de envelhecer no meio rural: Diálogos entre saúde e desenvolvimento. 2013. Dissertação (Mestrado em Desenvolvimento Rural) - Universidade Federal do Rio Grande do Sul.

PAZ, P. O. Violência fisica e homicidios em Mulheres rurais: vulnerabilidades de gênero e iniquidades sociais. Dissertação de Mestrado - 2013, EENF.

PINTO, J. M. Práticas avaliativas na atenção básica em saúde em municípios de pequeno porte: o sistema local de saúde no atendimento aos portadores de DCNT. 2011. Dissertação (Mestrado em Enfermagem) - Universidade Federal do Rio Grande do Sul, Coordenação de Aperfeiçoamento de Pessoal de Nível Superior.

RIQUINHO, D. L. A outra face dos determinantes sociais de saúde: subjetividades na construção do cotidiano individual e coletivo em uma comunidade rural. 2009. Dissertação (Mestrado em Enfermagem) - Universidade Federal do Rio Grande do Sul.

ROCHA, L. Sistemas locais de saúde e itinerários terapêuticos de adolescentes rurais em situação de gravidez e maternidade. 2009. Tese (Doutorado em Enfermagem) - Universidade Federal do Rio Grande do Sul, Coordenação de Aperfeiçoamento de Pessoal de Nível Superior.

ROCHA, L. Desnutrição e excesso de peso no meio rural de Arambaré - RS: (des)construindo idéias, repensando novos desafios. 2006. Dissertação (Mestrado em Enfermagem) Universidade Federal do Rio Grande do Sul, Coordenação de Aperfeiçoamento de Pessoal de Nível Superior.

ROESE, A. Planejamento regional ascendente e regionalização: atores e estratégias da organização dos fluxos de utilização dos serviços de saúde. 2012. Tese (Doutorado em Programa de Pós-Graduação em Enfermagem) - Universidade Federal do Rio Grande do Sul.

ROESE A. Fluxos e acesso dos usuários a serviços de média complexidade no município de Camaquã, RS. 2005. 200 f. Dissertação (Mestrado em Enfermagem) - Universidade Federal do Rio Grande do Sul, Coordenação de Aperfeiçoamento de Pessoal de Nível Superior.

RUIZ, E. N. F. Relações sociais nas situações de adoecimento crônico no rural: expressões de cuidado e de sofrimento na perspectiva da Dádiva. 2013. Tese (Doutorado em Programa de Pós- 
Graduação em Desenvolvimento Rural) - Universidade Federal do Rio Grande do Sul, Coordenação de Aperfeiçoamento de Pessoal de Nível Superior.

SANTOS, V. C. F. Articulação de ações e práticas em saúde: a mediação do cuidado na rede assistencial de São Lourenço do Sul/RS. 2013. Dissertação (Mestrado em Programa de PósGraduação em Enfermagem) - Universidade Federal do Rio Grande do Sul, Coordenação de Aperfeiçoamento de Pessoal de Nível Superior.

SANTOS, F. Práticas Agrícolas, Paisagem e Terroir: um estudo nas áreas fumicultoras do município de Camaquã - RS. 2010. Dissertação (Mestrado em Desenvolvimento Rural) UFRGS, Coordenação de Aperfeiçoamento de Pessoal de Nível Superior.

SANTOS, D. L. Condições de vida e saúde: análise dos determinantes sociais de acesso e utilização de serviços de saúde em Camaquã-RS. 2009. Dissertação (Mestrado em Programa de Pós-Graduação em Enfermagem) - Universidade Federal do Rio Grande do Sul.

SILVA, J. A. da. Estudo sociodemográfico e epidemiológico dos idosos do meio rural do município de Arambaré - RS. 2004. Dissertação (Mestrado em Enfermagem) - Universidade Federal do Rio Grande do Sul, Coordenação de Aperfeiçoamento de Pessoal de Nível Superior.

SODER, R. Indicadores de saúde e saneamento no meio rural de oito municípios da Metade Sul do RS. 2007. Dissertação (Mestrado em Enfermagem) - Universidade Federal do Rio Grande do Sul.

TONEZER, C. Velhices rurais na perspectiva do desenvolvimento ampliado-estudo de casos múltiplos/Camaquã e Canguçu - RS. Tese de Doutorado, 2011 PGDR.

TONEZER, C. Efeitos da cobertura previdenciária na situação de vida de idosos rurais de Santana da Boa Vista - RS. Dissertação de Mestrado - 2009, PGDR.

VIERA, V. Municípios de Camaquã e Canguçu: o relevo e sua morfodinâmica podem conduzir a uma condição de dinamismo ou estagnação dos sistemas de produção agrícola?. 2012. Tese (Doutorado em Geografia) - Universidade Federal do Rio Grande do Sul.

Recebido em: 09/11/2015. Aprovado em: 29/12/2015. 